\title{
MicroRNA as a Biomarker for Diagnostic, Prognostic, and Therapeutic Purpose in Urinary Tract Cancer
}

\author{
Amro M. Soliman ${ }^{1}\left(\mathbb{D}\right.$, Mohamed Soliman ${ }^{2,3}$, Srijit Das ${ }^{4, *(1)}$ and Seong Lin Teoh ${ }^{5, *(1)}$ \\ 1 Department of Biological Sciences—Physiology, Cell and Developmental Biology, University of Alberta, \\ Edmonton, AB T6G 2R3, Canada; amsherif@ualberta.ca \\ 2 Department of Microbiology, College of Medicine, Northern Border University, Arar 91431, Saudi Arabia; \\ mohamed.sherif@nbu.edu.sa \\ 3 Department of Parasitology, Faculty of Medicine, Mansoura University, Mansoura 35516, Egypt \\ 4 Department of Human \& Clinical Anatomy, College of Medicine \& Health Sciences, Sultan Qaboos University, \\ Al-Khoud, Muscat 123, Oman \\ 5 Department of Anatomy, Universiti Kebangsaan Malaysia Medical Centre, Cheras, \\ Kuala Lumpur 56000, Malaysia \\ * Correspondence: s.das@squ.edu.om (S.D.); teohseonglin@ppukm.ukm.edu.my (S.L.T.)
}

Citation: Soliman, A.M.; Soliman, M.; Das, S.; Teoh, S.L. MicroRNA as a Biomarker for Diagnostic, Prognostic, and Therapeutic Purpose in Urinary Tract Cancer. Processes 2021, 9, 2136. https://doi.org/10.3390/pr9122136

Academic Editor: Hsiuying Wang

Received: 27 October 2021

Accepted: 24 November 2021

Published: 26 November 2021

Publisher's Note: MDPI stays neutra with regard to jurisdictional claims in published maps and institutional affiliations.

Copyright: (c) 2021 by the authors. Licensee MDPI, Basel, Switzerland. This article is an open access article distributed under the terms and conditions of the Creative Commons Attribution (CC BY) license (https:// creativecommons.org/licenses/by/ $4.0 /)$.

\begin{abstract}
The incidence of urologic cancers, including kidney, upper tract urothelial, and bladder malignancies, is increasing globally, with a high percentage of cases showing metastasis upon diagnosis and low five-year survival rates. MicroRNA (miRNA), a small non-coding RNA, was found to regulate the expression of oncogenes and tumor suppressor genes in several tumors, including cancers of the urinary system. In the current review, we comprehensively discuss the recently reported up-or down-regulated miRNAs as well as their possible targets and regulated pathways involved in the development, progression, and metastasis of urinary tract cancers. These miRNAs represent potential therapeutic targets and diagnostic/prognostic biomarkers that may help in efficient and early diagnosis in addition to better treatment outcomes.
\end{abstract}

Keywords: miRNA; renal-cell carcinoma; urinary bladder cancer; upper tract urothelial carcinoma; diagnosis; prognosis; therapeutic targets

\section{Introduction}

Cancers of the urinary system involving the kidney, bladder, and upper urinary tract are showing an increase in their incidence globally [1]. For instance, kidney cancer was the seventh on the list of the most common malignancies, accounting for $3.3 \%$ of all cancers globally [2]. Renal-cell carcinoma (RCC) represents around 95\% of all kidney cancers [3], with clear-cell renal-cell carcinoma (ccRCC), arising from proximal tubules, encompassing about $75 \%$ of all cases [4]. Due to a high incidence rate and the considerable number of patients showing metastatic disease upon diagnosis [5], the economic burden of RCC reached approximately USD 556 million in the United States and USD 1.6 billion collectively in certain countries [5]. The urinary tract, starting from the renal collecting tubules and renal calyces, then the ureter and bladder up to the urethra, is lined with specialized epithelium termed as "urothelium" or "transitional epithelium", which possesses the same embryogenic origin. Urothelium undergoes malignant transformation, resulting in the development of different cancers of the urinary tract. Transitional cell carcinomas or urothelial carcinomas (UC) account for approximately $90 \%$ of these cancers; other rare types include squamous cell carcinoma and adenocarcinoma [6]. Most UCs originate from the urinary bladder causing urinary bladder cancer (UBC); whereas, upper tract urothelial carcinoma (UTUC), arising from renal pelvis and ureters, constitutes around $5-10 \%$ of all UCs [7]. Globally, UBC is the 9th most common cancer with more than 430,000 cases per year [8], and it ranks as the 13th most common cause of death among cancers [8]. 
UBC is also a male predominance disease, being the 7 th most common cancer in men worldwide [9].

microRNA (miRNA) is a short, non-coding RNA molecule discovered in 1993 by Ambros and Ruvkun groups in Caenorhabditis elegans [10-12]. The biogenesis of miRNAs involves several steps of pre-miRNA transcription in addition to post-transcriptional modifications by several regulatory enzymes such as Drosha and Dicer [13]. miRNAs regulate protein synthesis via inhibiting the transcription and translation of messenger (m)RNA, therefore influencing various biological processes such as cell proliferation, migration, and apoptosis in addition to the negative feedback regulation of protein-coding genes $[14,15]$. miRNAs bind to the $3^{\prime}$ untranslated region of mRNA, resulting in its degradation or blocking of its translation [13]. In addition, some miRNAs were found to up-regulate genes via enhancing of the expression their miRNAs either directly, which is dependent on the mRNA sequence, binding sites and associated binding proteins, or indirectly through miRNA-mediated suppression of repressive miRNAs [13]. Regarding cancer biology, miRNAs were found to regulate the expression of oncogenes and tumor suppressor genes. Thus, it plays a pivotal role in the pathogenesis, progression, and metastasis of various malignancies [16-22]. miRNA could act as an oncogenic miRNA (oncomiR) or tumor suppressor miRNA depending on the target genes. Therefore, oncomiRs were shown to be up-regulated in malignant cells; however, tumor suppressor miRNAs were reported to be down-regulated [23]. Along with targeting oncogenes or tumor suppressor genes, recent evidence supports a potential involvement of miRNAs in a cell-to-cell communication approach [24,25], influencing a variety of biological processes at the receiving sites [26]. This feature is attained via the circulating miRNAs released from the primary site in either free form or stalked in membrane-bound vesicles, e.g., exosomes [27]. In the last two decades, scientific research has suggested miRNAs as possible diagnostic/prognostic biomarkers and therapeutic targets in cancer management [28]. As a result, researchers and clinicians are currently examining the potential role of miRNAs in the diagnosis and management of various malignancies. In this review, we focus on the recent findings on miRNAs which were shown to possess diagnostic, prognostic, and therapeutic potential in cancers of the urinary tract.

\section{2. miRNAs in Kidney Cancer}

Among early studies aimed at profiling the expression levels of miRNAs in RCC, Nakada et al. reported significant alterations of $\sim 40$ miRNAs in ccRCC when compared with chromophobe renal-cell carcinomas (chRCC) and normal kidneys [29]. Among these miRNAs, miR-141 and miR-200c were markedly down-regulated. miR-141 and miR-200c are commonly known to target ZFHX1B mRNA. Therefore, down-regulation of miR-141 and miR-200c in RCC results in up-regulation of $Z F H X 1 B$, leading to suppression of $\mathrm{CDH} 1 / \mathrm{E}$-cadherin transcription and enhancing levels of vimentin, thus potentially augmenting epithelial-mesenchymal transition (EMT) [30]. EMT is a crucial process for tumor invasion and metastasis that is usually mediated by reduced expression of E-cadherin and loss of cell adhesion [31].

In the last few years, several studies have investigated the expression levels of various miRNAs and their biological functions in RCC (Table 1). These miRNAs were found to regulate interlacing networks of pathways, resulting in up- and/or down-regulation of oncogenes or tumor suppressor genes controlling tumor development, progression, and metastasis (Figure 1). Interestingly, some of these miRNAs showed a different pattern of expression when compared with other cancers. For instance, in contrast with prostatic cancer, where miR-34 is overexpressed, miR-34a was found to be down-regulated in RCC [32-34]. Moreover, distinct miRNA profiling was detected in different subtypes of kidney cancer, indicating a significant diagnostic and prognostic value [35]. For example, miRNAs such as miR-200b could be used to distinguish tumors with high histopathological similarities, such as oncocytomas and chromophobe RCCs. On the other hand, a panel of five miRNAs was consistently observed in at least three genitourinary organ tumors [33]. 
These miRNAs, comprising miR-136, miR-154, miR-337, miR-377, and miR-411, were identified to be down-regulated in ccRCC, human epithelial ovarian cancer, and UBC, suggesting potential applications of these miRNAs in identifying various tumors and selectively confirming the diagnosis of histological subtypes.

Table 1. miRNAs acting as oncomiRs or tumor suppressor genes in addition to their biological roles and possible targets in kidney cancer. miRNAs are arranged numerically based on being most relevant and frequently attributed in the literature.

\begin{tabular}{|c|c|c|c|c|c|c|c|}
\hline & miRNA & Samples & Target Genes/Function & Type & Level & Year & Ref. \\
\hline 1. & miR-21 & RCC cell line (ACHN) & $\begin{array}{l}\text { Promoted cell proliferation and } \\
\text { differentiation and decreased } \\
\text { apoptosis via regulating } \\
\text { MTOR-STAT3 signaling pathway }\end{array}$ & oncomiR & $\uparrow$ & 2016 & [36] \\
\hline 2. & $\operatorname{miR}-34 a$ & $\begin{array}{l}\text { FFPE kidney tissue } \\
\text { samples from patients } \\
\text { with primary RCC }\end{array}$ & TP53INP2, Tp53, DFFA & oncomiR & $\uparrow$ & 2017 & [37] \\
\hline 3. & $\operatorname{miR}-429$ & Cell lines (786-O, A498) & $\begin{array}{l}\text { Inhibited cell proliferation, } \\
\text { migration and invasion via } \\
\text { down-regulating } S p 1\end{array}$ & TS & $\downarrow$ & 2016 & [38] \\
\hline 4. & $\begin{array}{l}\text { miR-155-5p } \\
\quad \text { and } \\
\text { miR-210-3p }\end{array}$ & $\begin{array}{c}\text { Tumor tissue from } \\
\text { patients with newly } \\
\text { diagnosed and } \\
\text { histologically confirmed } \\
\text { ccRCC }\end{array}$ & $\begin{array}{l}\text { Associated with a high risk of } \\
\text { ccRCC recurrence by regulating } \\
\text { inflammation-related pathways and } \\
\text { IL-2 signaling events mediated by } \\
\text { PI3Ks as well as BCR signaling }\end{array}$ & oncomiR & $\uparrow$ & 2018 & [39] \\
\hline 5. & miR-106b & $\begin{array}{c}\text { RCC tissues and Cell } \\
\text { lines }(786-\mathrm{O} \text { and } A C H N)\end{array}$ & $\begin{array}{c}\text { Enhanced cell migration and } \\
\text { proliferation and suppressed } \\
\text { apoptosis via targeting } \\
\text { p21/WAF1/Cip1 pathway } \\
\text { and TWIST1 }\end{array}$ & oncomiR & $\uparrow$ & 2016 & [40] \\
\hline 6. & miR-206 & $\begin{array}{c}\text { ccRCC and } \\
\text { corresponding } \\
\text { non-cancerous tissues }\end{array}$ & $\begin{array}{l}\text { Inhibited cell proliferation by } \\
\text { inducing cell cycle arrest via } \\
\text { targeting cell cycle-related gene } \\
C D K 4, C D K 9 \text { and CCND1 }\end{array}$ & TS & $\downarrow$ & 2016 & [41] \\
\hline 7. & miR-22 & $\begin{array}{c}\text { Cell lines } \\
(786-\mathrm{O} \text { and A498) }\end{array}$ & $\begin{array}{l}\text { Suppressed cell proliferation, } \\
\text { migration and invasion by } \\
\text { regulating PTEN }\end{array}$ & TS & $\downarrow$ & 2016 & [42] \\
\hline 8. & miR-30a-5p & $\begin{array}{l}\text { ccRCC and adjacent } \\
\text { normal tissue samples } \\
\text { and 769-P cells }\end{array}$ & $\begin{array}{c}\text { Prevented cellular proliferation and } \\
\text { invasion in vitro and in vivo via } \\
\text { targeting ZEB2 and } \\
\text { suppressing EMT }\end{array}$ & TS & $\downarrow$ & 2017 & [43] \\
\hline 9. & $\begin{array}{l}\operatorname{miR}-21 \text { and } \\
\operatorname{miR}-221\end{array}$ & $\begin{array}{l}\text { Paired samples of } \\
\text { primary ccRCC and } \\
\text { adjacent non-tumorous } \\
\text { tissue }\end{array}$ & $\begin{array}{l}\text { Promoted cell cycle progression } \\
\text { and facilitated cell proliferation via } \\
\text { targeting p53 and p57 }\end{array}$ & oncomiR & $\uparrow$ & 2016 & [44] \\
\hline 10. & miR-508 & $\begin{array}{l}\text { ccRCC tissues and } \\
\text { paired adjacent } \\
\text { normal tissues } \\
\text { Papillary RCC cell lines } \\
\text { (Caki-2, ACHN) and } \\
\text { ccRCC cell lines } \\
\text { (786-O, A498) }\end{array}$ & $\begin{array}{l}\text { Decreased cell proliferation and } \\
\text { invasion via targeting } Z E B 1\end{array}$ & TS & $\downarrow$ & 2019 & [45] \\
\hline 11. & miR-384 & $\begin{array}{l}\text { RCC and normal tissues. } \\
\text { RCC cell lines (769-P, } \\
\text { 786-O, A498, SN12-PM6) }\end{array}$ & $\begin{array}{l}\text { Suppressed cell proliferation, } \\
\text { migration and cell cycle via } \\
\text { targeting } R A B 23\end{array}$ & TS & $\downarrow$ & 2018 & [46] \\
\hline
\end{tabular}


Table 1. Cont.

\begin{tabular}{|c|c|c|c|c|c|c|c|}
\hline & miRNA & Samples & Target Genes/Function & Type & Level & Year & Ref. \\
\hline 12. & miR-10a & $\begin{array}{l}\text { RCC tissues in addition } \\
\text { to cell lines } \\
\text { (A498 and 786-O) }\end{array}$ & $\begin{array}{l}\text { Inhibited cell invasion and EMT via } \\
\text { targeting BDNF }\end{array}$ & TS & $\downarrow$ & 2021 & [47] \\
\hline 13. & miR-10a-5p & Cell lines (786-O, A498) & $\begin{array}{l}\text { Inhibited cell migration and } \\
\text { invasion via targeting } S K A 1\end{array}$ & TS & $\downarrow$ & 2017 & [48] \\
\hline 14. & $\begin{array}{l}\text { miR-532-5p } \\
\text { and } \\
\text { miR-532-3p }\end{array}$ & $\begin{array}{l}\text { RCC tissues and cell } \\
\text { lines (786-O and A498) }\end{array}$ & $\begin{array}{l}\text { Attenuated proliferation, migration } \\
\text { and invasion by targeting } A Q P 9\end{array}$ & TS & $\downarrow$ & 2019 & [49] \\
\hline 15. & $\begin{array}{l}\text { miR-101-5p } \\
\text { and } \\
\text { miR-101-3p }\end{array}$ & $\begin{array}{l}\text { cRCC tissues and cell } \\
\text { lines (786-0 and A498) }\end{array}$ & $\begin{array}{l}\text { Induced cell cycle arrest and } \\
\text { apoptosis via targeting DONSON }\end{array}$ & TS & $\downarrow$ & 2020 & {$[50]$} \\
\hline 16. & $\begin{array}{l}\mathrm{miR}-149-5 \mathrm{p} \\
\text { and } \\
\text { miR-149-3p }\end{array}$ & $\begin{array}{l}\text { Tumor tissues from } \\
\text { patients with ccRCC }\end{array}$ & $\begin{array}{l}\text { Inhibited cell migration and } \\
\text { invasion via targeting FOXM1 }\end{array}$ & TS & $\downarrow$ & 2017 & {$[51]$} \\
\hline 17. & $\begin{array}{l}\text { miR-19a and } \\
\text { miR-19b }\end{array}$ & $\begin{array}{l}\text { Paired tumor and } \\
\text { adjacent normal kidney } \\
\text { tissues and cell lines } \\
\text { (786-O, Caki-1, Caki-2, } \\
\text { A498, SN12pm6, } \\
\text { ACHN) }\end{array}$ & $\begin{array}{l}\text { Promoted cell migration, } \\
\text { proliferation and invasion via } \\
\text { targeting } R H O B\end{array}$ & oncomiR & $\uparrow$ & 2018 & [52] \\
\hline 18. & $\operatorname{miR}-451 \mathrm{a}$ & $\begin{array}{l}\text { Tumor and normal } \\
\text { tissues from RCC } \\
\text { patients and cell lines } \\
(786-\mathrm{O}, \mathrm{A} 498)\end{array}$ & $\begin{array}{l}\text { Inhibited cell migration and } \\
\text { invasion via targeting } P M M 2\end{array}$ & TS & $\downarrow$ & 2018 & [53] \\
\hline 19. & $\operatorname{miR}-27$ & $\begin{array}{l}\text { Xenograft animal model } \\
\text { and RCC cell line } \\
(786-\mathrm{O})\end{array}$ & $\begin{array}{l}\text { Suppressed cell proliferation, } \\
\text { migration and invasion via } \\
\text { targeting EGFR and induced } \\
\text { cell apoptosis }\end{array}$ & TS & $\downarrow$ & 2016 & {$[54]$} \\
\hline 20. & miR-20b-5p & $\begin{array}{l}\text { RCC tissues and cell } \\
\text { lines }(293 \mathrm{~T})\end{array}$ & $\begin{array}{l}\text { - Inhibited cell proliferation } \\
\text { and migration } \\
\text { - promoted cellular apoptosis via } \\
\text { regulating PTEN, BRCA1 and } p 21\end{array}$ & TS & $\downarrow$ & 2016 & [55] \\
\hline 21. & miR-18a & $\begin{array}{l}\text { Cell lines (ACHN, } \\
\text { OSRC-2, HK-2, Caki-1, } \\
\text { 786-O and A498) }\end{array}$ & $\begin{array}{c}\text { Enhanced migration and invasion } \\
\text { via regulating HIF1A/PVT1 } \\
\text { pathway }\end{array}$ & oncomiR & $\uparrow$ & 2020 & [56] \\
\hline 22. & miR-106a-5p & $\begin{array}{l}\text { RCC tissues and cell } \\
\text { lines (OSRC-2, 786-O, } \\
\text { ACHN, Ketr-3) }\end{array}$ & $\begin{array}{l}\text { Decreased cell metastasis, } \\
\text { migration, invasion via } \\
\text { targeting PAK5 }\end{array}$ & TS & $\downarrow$ & 2017 & [57] \\
\hline 23. & miR-543 & $\begin{array}{l}\text { ccRCC tissues and } \\
\text { adjacent non-cancerous } \\
\text { tissues }\end{array}$ & $\begin{array}{l}\text { Promoted cell proliferation and } \\
\text { invasion via targeting KLF6 and p21 }\end{array}$ & oncomiR & $\uparrow$ & 2018 & [58] \\
\hline 24. & miR-200c & Metastatic ccRCC tissues & $\begin{array}{c}\text { Suppressed cell growth and } \\
\text { promoted apoptosis. Inhibited EMT } \\
\text { by targeting } Z E B 1 \text { and } Z E B 2\end{array}$ & TS & $\downarrow$ & 2019 & [59] \\
\hline 25. & miR-200a & RCC cell lines $(786-\mathrm{O})$ & $\begin{array}{l}\text { Suppressed cell growth, arrested } \\
\text { cell cycle, and enhanced cell } \\
\text { apoptosis by targeting SIRT1 }\end{array}$ & TS & $\downarrow$ & 2017 & [60] \\
\hline 26. & miR-200a-3p & $\begin{array}{l}\text { Cell lines }(786-\mathrm{O} \text {, } \\
\mathrm{ACHN})\end{array}$ & $\begin{array}{c}\text { Inhibited cell proliferation by } \\
\text { inducing apoptosis via } \\
\text { down-regulating SPAG9 }\end{array}$ & TS & $\downarrow$ & 2016 & [61] \\
\hline
\end{tabular}


Table 1. Cont.

\begin{tabular}{cccccccc}
\hline & miRNA & Samples & Target Genes/Function & Type & Level & Year & Ref. \\
\hline 27. & miR-30e-3p & $\begin{array}{c}\text { Cell lines } \\
\text { (A498 and 786O) }\end{array}$ & $\begin{array}{c}\text { Inhibited cell invasion and } \\
\text { migration via targeting SNAI1 }\end{array}$ & TS & $\downarrow$ & 2017 & [62] \\
\hline 28. & miR-101 & $\begin{array}{c}\text { RCC tissues from } \\
\text { patients before and } \\
\text { following sunitinib } \\
\text { treatment }\end{array}$ & $\begin{array}{c}\text { Down-regulation of miR-101 was } \\
\text { associated with resistance to } \\
\text { sunitinib. Inhibited cell migration } \\
\text { and invasion via targeting UHRF1 }\end{array}$ & TS & $\downarrow$ & 2016 & {$[63]$} \\
\hline
\end{tabular}

TS: tumor suppressor miRNA, RCC: renal-cell carcinoma, EMT: Epithelial-mesenchymal transition, BDNF; Brain-derived neurotrophic factor, TWIST1: Twist Family BHLH Transcription Factor 1, ZEB: Zinc Finger E-Box Binding Homeobox, AQP9: Aquaporin 9, UHRF1: Ubiquitin-like with PHD and ring finger domains 1, IL: interleukin, PI3K: phosphoinositide 3-kinase, BCR: B cell-receptor, SNAI1: Snail Family Transcriptional Repressor 1, FOXM1: Forkhead box protein M1, KLF6: Krüppel-like factor 6, CDK: cyclin-dependent kinase, CCND1: Cyclin D1, PTEN: phosphatase and tensin homolog, RHOB: Ras Homolog Family Member B, DONSON: DNA Replication Fork Stabilization Factor, TP53INP2: Tumor Protein P53 Inducible Nuclear Protein 2, DFFA: DNA Fragmentation Factor Subunit Alpha, EGFR: epidermal growth factor receptor, SIRT1: Sirtuin 1, BRCA1: Breast cancer type 1, HIF1A: Hypoxia-Inducible Factor 1 Subunit Alpha, PVT1: plasmacytoma variant translocation 1, PAK5: P21 (RAC1) Activated Kinase 5, MTOR: mammalian target of rapamycin, STAT3: Signal Transducer And Activator Of Transcription 3, PMM2: phosphomannomutase 2, RAB23: Ras-related protein Rab-23, SPAG9: Sperm Associated Antigen 9, SKA1: Spindle and kinetochore-associated protein 1.

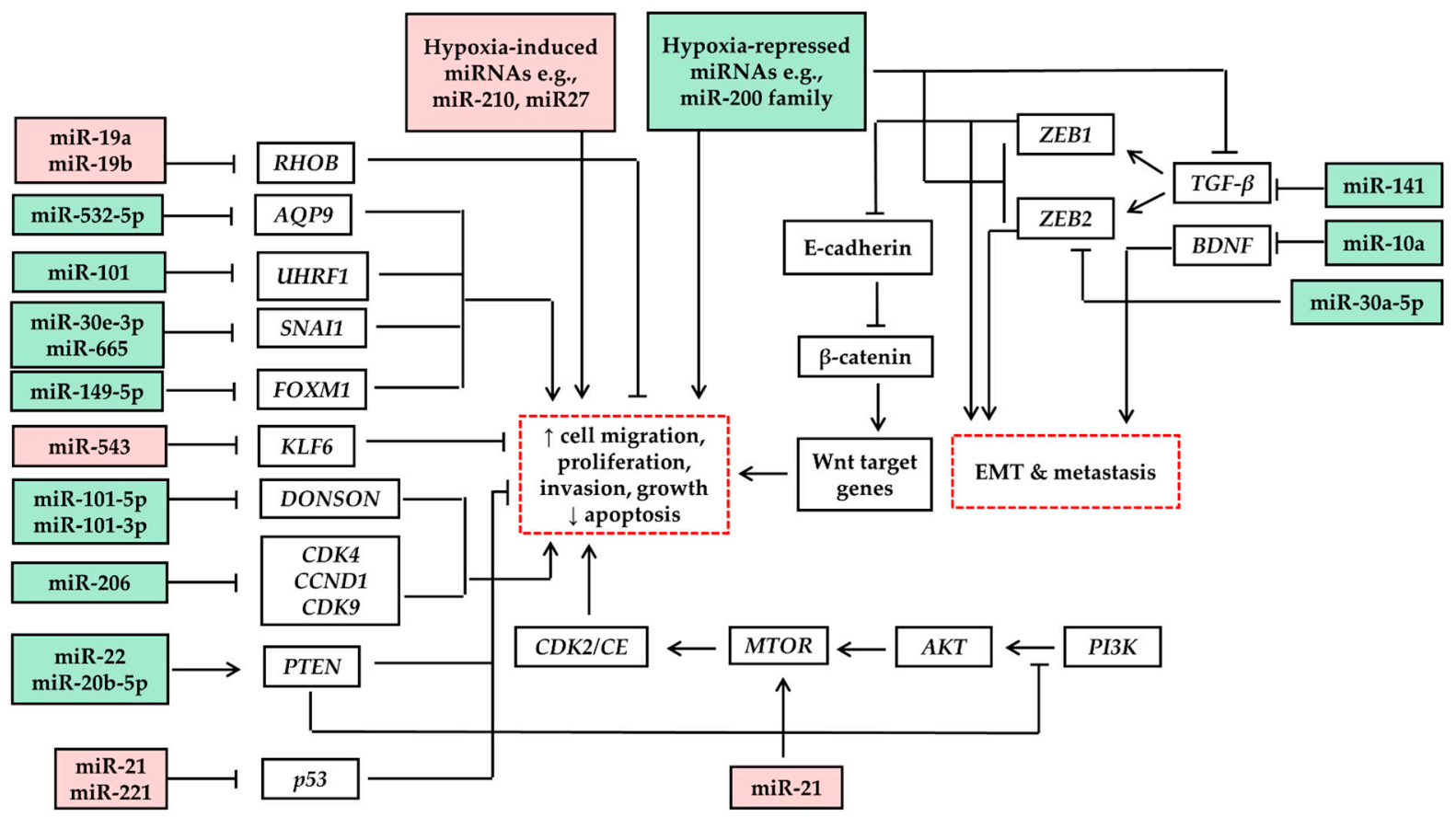

Figure 1. miRNAs up-regulated (red-colored) and down-regulated (green-colored) in renal-cell carcinoma and their target genes and regulated pathways. EMT: Epithelial-mesenchymal transition, TGF- $\beta$ : transforming growth factor-beta, BDNF; Brain-derived neurotrophic factor, ZEB: Zinc Finger E-Box Binding Homeobox, PI3K: phosphoinositide 3-kinase, AKT: AKT Serine/Threonine Kinase 3, MTOR: mammalian target of rapamycin, CDK: cyclin-dependent kinase, RHOB: Ras Homolog Family Member B, AQP9: Aquaporin 9, UHRF1: Ubiquitin-like with PHD and ring finger domains 1, SNAI1: Snail Family Transcriptional Repressor 1, FOXM1: Forkhead box protein M1, KLF6: Krüppel-like factor 6, DONSON: DNA Replication Fork Stabilization Factor, CCND1: Cyclin D1, PTEN: phosphatase and tensin homolog.

RCC is well-recognized for cancer-associated hypoxia and enhanced angiogenesis. miRNA regulation through both processes has been well studied. For instance, hypoxiaregulated miRNAs, including miR-210, were remarkably up-regulated in RCC. miRNA profiling in RCC was broadly linked to angiogenesis, a pivotal biological process for tumor growth and progression. Researchers reported that hypoxic growth factors enhanced the expression of miR-296 in vascular endothelial cells [64]. MiR-296 has been shown to target the hepatocyte growth factor-regulated tyrosine kinase substrate (HRS), inhibiting 
the degradation of angiogenic growth factor receptors such as VEGFR2 and PDGFR- $\beta$, therefore enhancing angiogenesis [64].

Likewise, up-regulation of miR-29b was detected in RCC, where it was associated with high levels of von Hippel-Lindau (VHL) tumor suppressor protein [65]. miR-29b targets TPA-inducible sequence 11-B (TIS11B), which is a negative regulator of vascular endothelial growth factor (VEGF), thus enhancing new blood vessel formation. Others investigated VHL-regulated miRNAs, where miRNA expression in RCC was reported to be either hypoxia-inducible factors (HIFs)-dependent or HIF-independent [66]. miR-210, miR-155, let-7i, and members of the miR-17-92 cluster, are involved in the hypoxic pattern of gene expression [66]. Among them, miR-210 was distinctly up-regulated and its levels correlated inversely with the patient survival rate. miR-210 was suggested to target ironsulfur cluster assembly (ISCU1/2), which codes for a protein that enhances the assembly of iron-sulfur clusters and prosthetic groups that are critical for electron transport and mitochondrial oxidation-reduction reactions, thus repressing mitochondrial respiration, thereby facilitating tumor cell adaptation to hypoxia and intensely influencing cell survival and function [67]. Other miRNAs such as miR-23b act as oncomiRs in renal cancer by targeting proline oxidase $(P O X)$, a potent mitochondrial tumor suppressor that inhibits proliferation and promotes apoptosis via the generation of reactive oxygen species (ROS), in addition to blocking HIF signaling [68].

Nearly one third of RCC cases are initially diagnosed with metastases, and about half of patients diagnosed with localized stage disease showed metastasis subsequent to complete resection of the primary tumor $[69,70]$. Although several therapeutic agents have been approved for treatment of metastatic stage [71], the determination of prognosis is extremely critical for choosing and initiating the proper plan of systemic treatments. Therefore, identifying prognostic biomarkers is usually the first step, shedding light on potential biological pathways of cancer development as well as developing efficacy-based criteria for that therapeutic intervention [72,73]. Despite the long-term use of the scoring system in the prognostication of renal cancer [74,75], it still lacks sensitive and specific genomic biomarkers that might reflect the underlying stage-specific tumor biology associated with disease development and progression [76,77]. These molecular prognostic biomarkers reflect genetic aberrations and thus promote the prediction of survival outcomes [78-80]. In the case of metastatic RCC, blood and urine miRNAs may represent non-invasive prognostic biomarkers since they remain considerably stable and intact via binding to lipoproteins, or being inside circulating membrane microvesicles, e.g., exosomes [81,82]. The feasibility of exosome sampling opened the door towards clinical applications involving diagnosis, prognosis, tumor assessment and therapies [83]. Recently reported studies demonstrated the possible use of free and exosomal serum and urinary miRNAs as diagnostic biomarkers with high sensitivity and specificity (Table 2). Similarly, levels of these miRNAs in blood or urine indicated a prognostic value. For instance, miRNAs in 44 metastatic RCCs were evaluated for survival analysis. Among them, researchers identified six miRNAs that were associated with overall survival (OS), including miR-let-7i-5p, miR-26a-1-3p and miR-615-3p [84]. miR-let-7i-5p with the clinical factor-based scoring was found to improve survival prediction from an area under the curve of 0.58 to an average of 0.64 during a 48-month follow-up [84]. Likewise, the suggested model managed to define a high-risk group with a median survival of 14 months and a low-risk group of 39 months. Despite the current promising potential, the miRNA-based prognostic determination still requires further validation. 
Table 2. miRNAs and their diagnostic potentials in renal cell carcinoma.

\begin{tabular}{cccccc}
\hline miRNA & Samples & Level & Sensitivity & Specificity & Ref. \\
\hline miR-144-3p & Plasma & $\uparrow$ & $87.10 \%$ & $83.00 \%$ & {$[85]$} \\
miR-210 & Plasma & $\uparrow$ & $82.50 \%$ & $80.00 \%$ & {$[86]$} \\
miR-221and miR-222 & Plasma & $\uparrow$ & $72.50 \%$ & $33.30 \%$ & {$[87]$} \\
miR-122-5p and miR-206 & Serum & $\uparrow$ & $57.10 \%$ & $83.80 \%$ & {$[88]$} \\
miR-210 & Serum & $\uparrow$ & $70.00 \%$ & $62.20 \%$ & {$[89]$} \\
miR-1233 & Serum & $\uparrow$ & $81.00 \%$ & $76.00 \%$ & {$[89]$} \\
miR-30c-5p & Urine & $\downarrow$ & $68.57 \%$ & $100.0 \%$ & {$[90]$} \\
let-7 & Urine & $\uparrow$ & $71.00 \%$ & $81.00 \%$ & {$[91]$} \\
miR-34b-5p and miR-1183 & Urine & $\uparrow$ & $69.00 \%$ & $65.00 \%$ & {$[92]$} \\
miR-126-3p and miR-34b-5p & Urine & $\uparrow$ & $82.80 \%$ & $65.00 \%$ & {$[92]$} \\
miR-126-3p and miR-126-5p & Urine & $\uparrow$ & $72.40 \%$ & $70.00 \%$ & {$[92]$} \\
miR-150-5p and miR-126-3p & Urine & $\uparrow$ & $72.40 \%$ & $80.00 \%$ & {$[92]$} \\
miR-150 and 5p and miR-1183 & Urine & $\uparrow$ & $86.20 \%$ & $55.00 \%$ & {$[92]$} \\
miR-210 & Urine & $\uparrow$ & $57.80 \%$ & $80.00 \%$ & {$[93]$} \\
miR-486-5p and miR-126-3p & Urine & $\uparrow$ & $72.40 \%$ & $60.00 \%$ & {$[92]$} \\
\hline
\end{tabular}

\section{3. miRNAs in Upper Tract Urothelial Carcinoma}

UTUC is considered an uncommon genitourinary malignancy with an incidence rate of 1-2 cases per 100,000 individuals per year [94]. However, the majority of UTUC patients are diagnosed at an advanced stage, leading to poor prognoses and high mortality rates. Severe hematuria and/or renal obstruction are common signs of the disease. The diagnosis is confirmed by imaging, urine cytology, and biopsy. Subsequent to diagnosis, grading and staging of the tumor determine the treatment options. For example, in low-risk patients, nephron-sparing segmental ureterectomy and endoscopic ablation are commonly used $[95,96]$. However, in advanced cases, radical nephroureterectomy with an ipsilateral bladder cuff is the standard. Currently, recurrence-free survival (RFS) and OS are predicted using tumor grading based on histopathological findings and muscle invasion [94]. Yet, there is still room for improvement. A group of researchers reported that the currently established pathological staging and histological grading are inadequate to effectively predict tumor behavior [97]. The potential use of molecular biomarkers in addition to the well-characterized histopathological classification is crucial for risk stratification. The correct and early diagnosis is pivotal for determining the appropriate approach for treatment. Therefore, molecular biomarkers that can complement and enhance the current strategies for UTUC detection are being investigated to reduce morbidity and mortality rates. Examining wide-range miRNA expression patterns in tissue samples from cases with UTUC characterized a list of 26 miRNAs differentially expressed between patients with progressing and non-progressing UTUC [97]. Others have investigated the circulating miRNAs and their role as molecular biomarkers in the diagnosis and prognosis of UTUC. Interestingly, in UTUC patients, there was a remarkable increase in the serum levels of a few circulating miRNAs that could distinguish UTUC from controls, including miR-664a-3p, miR-423-5p, miR-33b-3p, miR-26a-5p, miR-16-5p, and let-7c [98].

miRNA profiling of formalin-fixed paraffin-embedded (FFPE) tissue sections from RCC, UTUC, and healthy cases demonstrated several miRNAs that were significantly dysregulated in cancerous vs. normal tissue. Surprisingly, clusters of miRNAs distinguished UTUC from RCC and classified various RCC subtypes [99]. Next-generation sequencing of UTUC, and normal tissue from 22 patients revealed that miR-30a-5p was markedly downregulated in UTUC [100]. In vitro up-regulation of miR-30a-5p inhibited cell proliferation, migration and EMT in cultured UTUC cells. Mechanistically, miR-30a-5p was found to up-regulate claudin- 5 in UTUC cells in the tight junction pathway. Therefore, they represent a potential therapeutic strategy for UTUC treatment via genetic delivery [100]. Balkan endemic nephropathy (BEN) was found to be strongly associated with UTUC. miRNA profiling of UTUC tissues from patients with BEN and without BEN reported several miRNAs that were differentially expressed in both tissues, suggesting these miRNAs as potential 
diagnostic biomarkers [101]. Aristolochic acid (AA), a carcinogenic and nephrotoxic compound commonly isolated from Aristolochiaceae, was shown to be associated with UTUC pathogenesis, with the underlying mechanism still undetermined. Profiling of miRNAs in AA-induced UTUC and non-AA-induced UTUC tissues revealed 29 miRNAs that were differentially expressed. These miRNAs were suggested to target several genes, such as AKT3, PSEN1, FGFR3 and VEGFA, which regulate tumor progression and growth [102]. Notably, most recent miRNAs studies in UTUC focused on examining miRNAs as diagnostic and/or prognostic biomarkers, with few of these reports investigating the biological pathways involved (Table 3).

Table 3. miRNAs and their diagnostic and/or prognostic values in upper tract urothelial carcinoma.

\begin{tabular}{cccc}
\hline miRNA & Samples & Level & Diagnostic/Prognostic Value \\
\hline miR-31 and miR-149 & & Ref. & $\begin{array}{c}\text { - Independently associated with high tumor } \\
\text { progression, recurrence, stage and } \\
\text { cancer-specific survival }\end{array}$ \\
& & $\uparrow$ & $\begin{array}{c}\text { - Differentiated two groups with a significantly } \\
\text { different probability of tumor progression (HR: } \\
\end{array}$ \\
& & 4.78) and death (HR: 2.76)
\end{tabular}

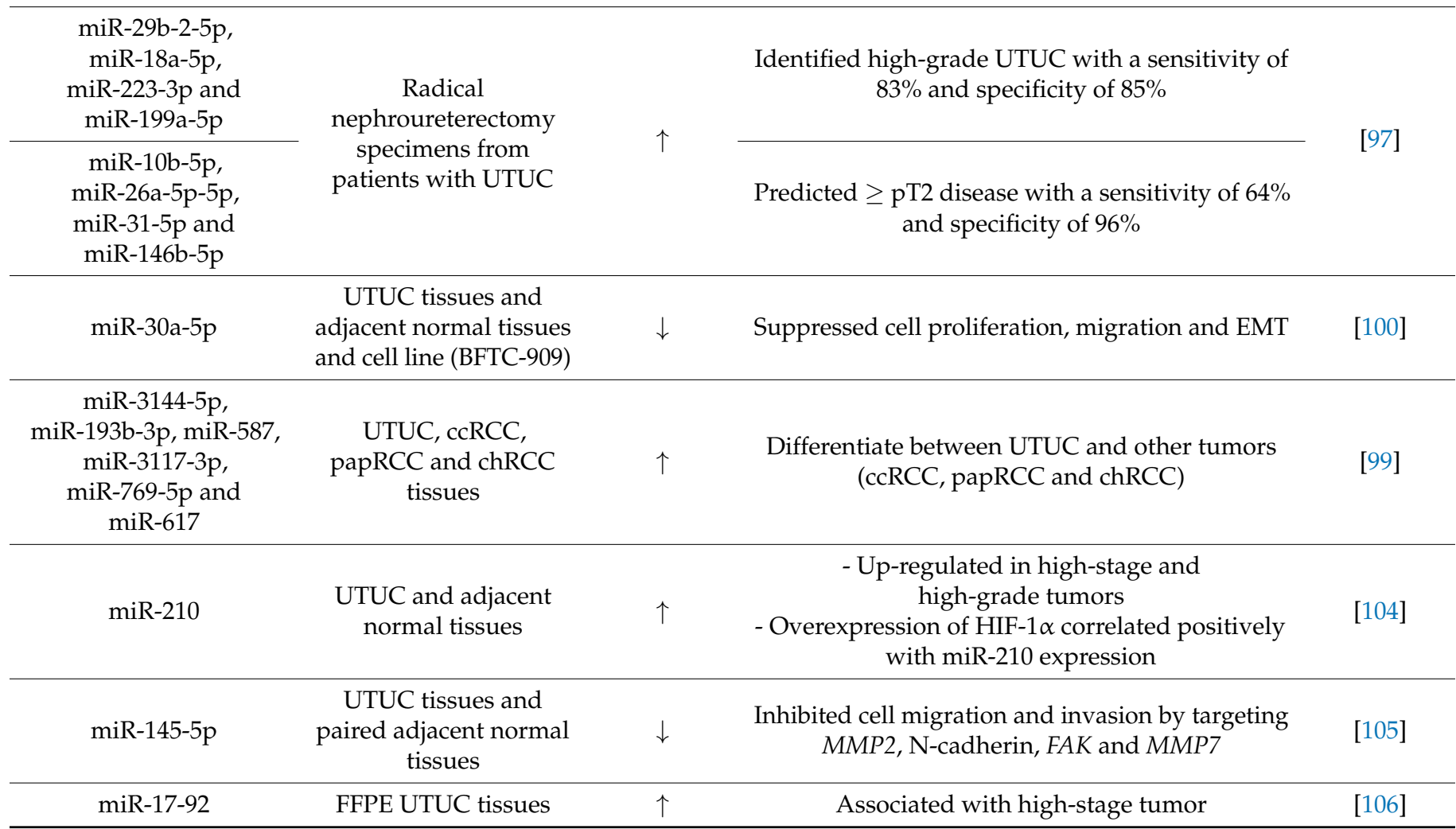

UTUC: Upper Tract Urothelial Carcinoma, ccRCC: clear-cell renal-cell carcinoma, papRCC: papillary renal-cell carcinoma, chRCC: chromophobe renal-cell carcinoma, EMT: Epithelial-mesenchymal transition, HIF1A: Hypoxia-Inducible Factor 1 Subunit Alpha, MMP: matrix metalloproteinase, FAK: Focal adhesion kinase.

\section{4. miRNAs in Urinary Bladder Cancer}

miRNA profiling in UBC began two decades ago, with several studies examining differential miRNA expression in the disease. Gottardo et al. reported a significant overexpression of several miRNAs in cancerous tissue, including miR-223, miR-221, miR-185, miR-203, miR-23a, and miR-205 [107]. Others showed altered expression of various miRNAs, including a reduction in the level of miR-145, and up-regulation of miR-21 [108]. Recently, several studies investigated the expression levels of various miRNAs and their biological functions in UBC (Table 4). These miRNAs regulate the expression of oncogenes or tumor suppressor genes involved in tumor development, progression, and metasta- 
sis (Figure 2). For example, functional analysis of miR-129 revealed targeting of SOX4 transcription factor and GALNT1, resulting in apoptosis evasion [108]. Interestingly, in normal urothelium tissue from patients with UBC, several miRNAs showed altered expression compared to samples from disease-free controls. Moreover, specific miRNAs were differentially expressed in a phenotype-specific manner in a way that could predict disease progression. A group of researchers reported a phenotype-specific expression of miRNAs such as miR-21/205 in various types of UBC [109], which collectively with other similar studies helped in understanding the tumor biology. Additionally, miRNA profiling significantly contributed to differentiating UBC with regard to grading. Lowand high-grade UBC were shown to have distinctive molecular pathways [110], in which miRNA alterations were noticed. For instance, low- and high-grade UBC had few miRNA signatures in common such as miR-211, miR-518e, miR-133b and miR-204, with several distinct miRNAs that were differentially expressed [111]. High-grade UBC was associated with up-regulation of miRNA-21 that suppresses p53. However, in low-grade UBC, many miRNAs were down-regulated, such as miRNAs-99a/100, which was correlated with upregulation of FGFR3 [111]. miRNAs' down-regulation was mainly attributed to promoter hypermethylation [51]. In contrast, high-grade non-invasive and invasive UBC shared many miRNA alterations, indicating the critical role of these miRNAs in tumor progression and behavior change [110,112].

Table 4. miRNAs acting as oncomiRs or tumor suppressor genes in addition to their biological roles and possible targets in urinary bladder cancer. miRNAs are arranged numerically based on being most relevant and frequently attributed in the literature.

\begin{tabular}{|c|c|c|c|c|c|c|c|}
\hline & miRNA & Samples & Target Genes/Function & Type & Level & Year & Ref. \\
\hline 1. & miR-145-5p & $\begin{array}{l}\text { UBC tissues and cell } \\
\text { lines (T24 and 5637) }\end{array}$ & $\begin{array}{l}\text { Inhibited cell proliferation and } \\
\text { migration via targeting TAGLN2 }\end{array}$ & TS & $\downarrow$ & 2018 & [113] \\
\hline 2. & miR-99a & $\begin{array}{l}\text { UBC and paired } \\
\text { adjacent non-cancerous } \\
\text { tissues }\end{array}$ & $\begin{array}{l}\text { Inhibited invasion via targeting } \\
\text { ST5, MTOR, FGFR3 and IGF-1 }\end{array}$ & TS & $\downarrow$ & 2017 & [114] \\
\hline 3. & miR-497 & $\begin{array}{l}\text { - UBC and adjacent } \\
\text { normal tissues } \\
\text { - Cell lines (T24 and } \\
\text { BIU-87) }\end{array}$ & $\begin{array}{l}\text { Inhibited cell migration, } \\
\text { invasiveness and metastasis via } \\
\text { reducing vimentin and } \alpha \text {-smooth } \\
\text { muscle actin }\end{array}$ & TS & $\downarrow$ & 2017 & [115] \\
\hline \multirow[b]{2}{*}{4.} & \multirow[b]{2}{*}{ miR-124-3p } & $\begin{array}{l}\text { UBC tissues and } \\
\text { cell lines }\end{array}$ & $\begin{array}{l}\text { Suppressed cell proliferation and } \\
\text { migration, and promoted cell } \\
\text { apoptosis via targeting } A U R K A\end{array}$ & TS & $\downarrow$ & 2017 & [116] \\
\hline & & $\begin{array}{l}\text { Clinical specimens from } \\
\text { UBC patients and } \\
\text { bladder cancer cell lines }\end{array}$ & $\begin{array}{c}\text { Suppressed cell migration and } \\
\text { invasion via targeting ITGA3 and } \\
\text { its downstream FAK/PI3K/AKT } \\
\text { and FAK/Src pathways }\end{array}$ & TS & $\downarrow$ & 2019 & [117] \\
\hline 5. & miR-130b & $\begin{array}{l}\text { UBC tissues and } \\
\text { cell lines }\end{array}$ & $\begin{array}{l}\text { Promoted cell proliferation and } \\
\text { invasion via targeting VGLL4 }\end{array}$ & oncomiR & $\uparrow$ & 2018 & [118] \\
\hline 6. & miR-186 & $\begin{array}{l}\text { UBC tissues and } \\
\text { blood/urine samples }\end{array}$ & $\begin{array}{l}\text { - Inhibited invasion and metastasis } \\
\text { via targeting } V E G F-C \\
\text { - miR-186 was reduced in tumor } \\
\text { tissues, blood and urine }\end{array}$ & TS & $\downarrow$ & 2017 & [119] \\
\hline 7. & miR-135a & $\begin{array}{l}\text { UBC and adjacent } \\
\text { normal tissues }\end{array}$ & $\begin{array}{l}\text { Enhanced cell proliferation, } \\
\text { migration, invasion and tumor } \\
\text { growth via targeting GSK3 } \beta \text { and } \\
\text { E-cadherin in addition to activating } \\
\text { Wnt/ } \beta \text {-catenin signaling pathway }\end{array}$ & oncomiR & $\uparrow$ & 2018 & [120] \\
\hline 8. & miR-1-3p & $\begin{array}{l}\text { UBC tissues with } \\
\text { adjacent normal tissues }\end{array}$ & $\begin{array}{l}\text { Suppressed cell proliferation and } \\
\text { invasion and promoted apoptosis } \\
\text { via targeting CCL2 }\end{array}$ & TS & $\downarrow$ & 2017 & [121] \\
\hline
\end{tabular}


Table 4. Cont.

\begin{tabular}{|c|c|c|c|c|c|c|c|}
\hline & miRNA & Samples & Target Genes/Function & Type & Level & Year & Ref. \\
\hline 9. & miR-373 & $\begin{array}{l}\text { UBC and adjacent } \\
\text { healthy tissues and } \\
\text { blood samples }\end{array}$ & $\begin{array}{c}\text { - Promoted cell proliferation, } \\
\text { migration and invasion via } \\
\text { up-regulation of } E G F R \\
\text { - Serum miR-373 can accurately } \\
\text { predict UBC }\end{array}$ & oncomiR & $\uparrow$ & 2018 & [122] \\
\hline 10. & miR-125b-5p & $\begin{array}{c}\text { Cell lines (T24, RT4, J82, } \\
\text { 5637, SV-HUC-1) and } \\
\text { UBC tissues }\end{array}$ & $\begin{array}{l}\text { - Low miR-125b-5p expression } \\
\text { correlated with shorter 5-year } \\
\text { survival time } \\
\text { - Inhibited cell viability and } \\
\text { migration and induced cell } \\
\text { apoptosis by targeting HK2 through } \\
\text { suppressing PI3K/AKT pathway }\end{array}$ & TS & $\downarrow$ & 2020 & [123] \\
\hline 11. & miR-328-3p & $\begin{array}{l}\text { Tumor tissues from } \\
\text { patients with UBC }\end{array}$ & $\begin{array}{c}\text { - Suppressed cell proliferation, } \\
\text { migration and invasion by } \\
\text { targeting ITGA5 } \\
\text { - Inhibited EMT and } \\
\text { PI3K/AKT pathway }\end{array}$ & TS & $\downarrow$ & 2019 & [124] \\
\hline
\end{tabular}

- Cell lines (J82, T24

UM-UC-3, SV-HUC-1) -

12. miR-154

$\mathrm{UBC}$ and paired adjacent non-cancerous bladder tissues

- Low expression of miR-154 was associated with poor survival outcomes

- Inhibited cell proliferation, migration, and invasion in cultured cancer cells as well as cell growth in xenograft model via targeting ATG7

Reversed EMT progression and inhibited cell migration via targeting SMAD3 and SNAI1

Inhibited cell proliferation and

UBC tissues and
cell lines
invasion by targeting $H M G B 3$ and regulation of nuclear expression of $\beta$-catenin as well as activation of Wnt/ $\beta$-catenin signaling pathway

- Low miR-153 expression was associated with advanced tumor stage and poor OS

- miR-153 inhibited cancer growth via promoting cell apoptosis and suppressing migration, invasion, and EMT via targeting IDO1 and

IL6/STAT3/VEGF signaling

Paired UBC and adjacent non-tumorous

16. $\operatorname{miR}-300$ bladder mucosal tissues as well as cell lines (T24,
Inhibited cell migration via targeting SP1 and regulating the SP1/MMP9 pathway

UM-UC3, SV-HUC-1)

TS: tumor suppressor miRNA, UBC: urinary bladder cancer, EMT: Epithelial-mesenchymal transition, HMGB3: high-mobility group protein B3, EGFR: epidermal growth factor receptor, IDO1: Indoleamine 2,3-Dioxygenase 1, STAT3: Signal Transducer and Activator of Transcription 3, VEGF: vascular endothelial growth factor, AURKA: Aurora Kinase A, ITGA: Integrin Subunit Alpha, PI3K: phosphoinositide 3-kinase, AKT3: AKT Serine/Threonine Kinase 3, VGLL4: Vestigial Like Family Member 4, TAGLN2: Transgelin 2, MMP9: Matrix Metallopeptidase 9, ATG7: Autophagy Related 7, ST5: tumorigenicity 5, FGFR3: fibroblast growth factor receptor 3, IGF-1: insulin-like growth factor 1, MTOR: mammalian target of rapamycin, HK2: Hexokinase 2, SNAI1: Snail Family Transcriptional Repressor 1, GSK-3 $\beta$ : Glycogen synthase kinase-3 $\beta$, CCL2: C-C Motif Chemokine Ligand 2. 


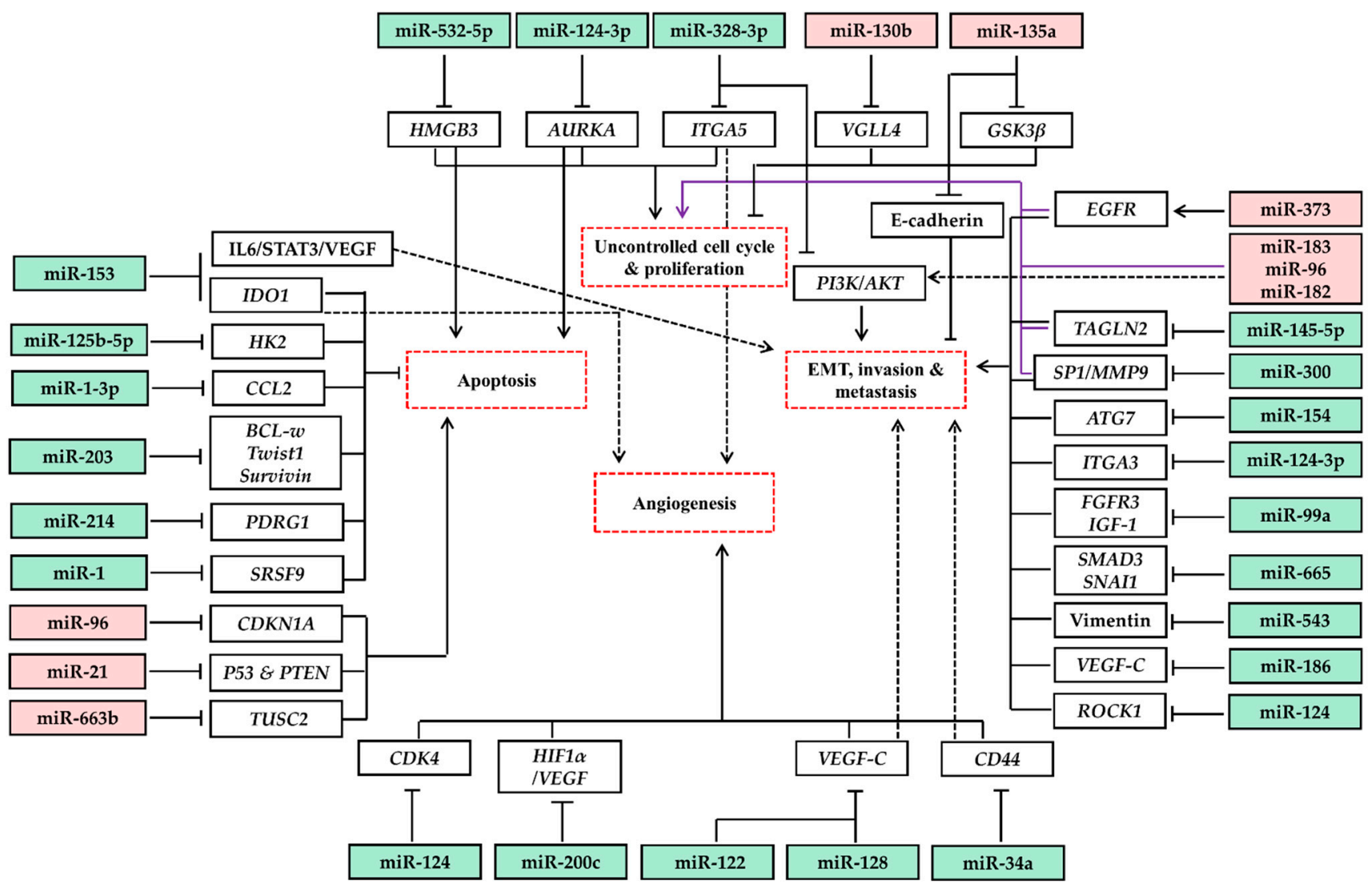

Figure 2. miRNAs up-regulated (red-colored) and down-regulated (green-colored) in urinary bladder cancer and their target genes. EMT: Epithelial-mesenchymal transition, EGFR: epidermal growth factor receptor, TAGLN2: Transgelin-2, MMP: matrix metaloprotenas, ATG7: Autophagy Related 7, ITGA: Integrin Subunit Alpha, FGFR: fibroblast growth factor receptor, IGF-1: insulin growth factor-1, SNAI1: Snail Family Transcriptional Repressor 1, VEGF: vascular endothelial growth factor, ROCK1: Rho Associated Coiled-Coil Containing Protein Kinase 1, HIF1A: Hypoxia-Inducible Factor 1 Subunit Alpha, CDK: cyclin-dependent kinase, STAT3: Signal Transducer And Activator Of Transcription 3, IDO: indoleamine 2,3-dioxygenase, HK2: hexokinase 2, CCL2: C-C Motif Chemokine Ligand 2 TWIST1: twist Family BHLH Transcription Factor 1, PDRG1: P53 And DNA Damage Regulated 1, SRSF9: serine/arginine-rich splicing factor 9, PTEN: phosphatase and tensin homolog, CDKN1A: Cyclin-Dependent Kinase Inhibitor 1A, TUSC2: Tumor Suppressor 2, Mitochondrial Calcium Regulator.

Regarding the mechanistic contribution of miRNAs to UBC development and progression, a group of researchers demonstrated a critical role for the miR-200 family via targeting ERRF-1 [130], which regulates epidermal growth factor receptor (EGFR) and acts as an independent mediator of EMT. Therefore, the down-regulation of miR-200 enhances EMT and cellular migration. The loss of miR-200 was suggested to be induced by hypermethylation of its promoter as well as a correlated increase in the expression of the TWIST1 transcription factor [131]. Likewise, the overexpression of ZEB1 in UBC cases, concurrently with low levels of miR-200, promoted EMT via suppressing E-cadherin [132]. Collectively, TWIST1 could silence miR-200 family members along with up-regulation of ZEB1, which in turn represses E-cadherin and directly targets miRs-141/200, constituting a feedback loop [133].

Several miRNAs are involved in the avoidance of apoptosis. miR-133b and miR-203 were shown to target $B C L 2$, a family of proteins that can inhibit the intrinsic pathway of apoptosis, thus promoting cell survival. On the other hand, miR-195, miR-203, and miR-497 regulated BIRC5 (survivin), a suppressor of apoptosis protein family [108]. Unlike miR-129, which directly targets genes involved in apoptosis protein transcription and expression, miR-1 has been shown to increase apoptosis by increasing caspase 3 and 7 activity by targeting SRSF9, an apoptosis inhibitor [134]. Notably, miR-1 was significantly down-regulated in UBC samples and cultured cells [134]. 
Cell cycle regulatory gene expression is controlled via a network of miRNAs contributing to cell survival and apoptosis escape. Among these genes, CCNE1/2, CDC25A, and PKMYT1 were revealed to be directly regulated by miR-144-5p and miR-449a [135]. CDK4 and CDK6 are likewise regulated by miR-124-3p, miR-29c, and miR-449a [135]. FSCN1 and LASP1 genes code for protein essential for filopodia and lamellipodia involved in mediating dynamics of actin filaments during EMT. FSCN1 was found to be regulated by miR-133a and miR-145 [136], whereas miR-1/133a and miR-218 control the expression of LASP1 [137]. Other miRNAs regulate the expression of matrix metalloproteinases (MMPs), endopeptidases that facilitate tumor invasion and metastasis via degrading extracellular matrix proteins and cell surface receptors, in addition to the release of apoptotic ligands (e.g., FAS). In UBC, reduced expression of miR-200b directly regulates MMP16, which activates other MMPs (such as MMP-2 and MMP-9) and growth factors to facilitate cell migration [138]. It is also worth mentioning that differential miRNA expression in the serum and urine of UBC patients was reported in several clinical trials, suggesting their potential role as diagnostic biomarkers (Table 5).

Table 5. miRNAs and their diagnostic potentials in urinary bladder cancer.

\begin{tabular}{|c|c|c|c|c|c|}
\hline miRNA & Samples & Level & Sensitivity & Specificity & Ref. \\
\hline miR-422a-3p, miR-486-3p, miR-103a-3p and miR-27a-3p & Serum & $\uparrow$ & $90.0 \%$ & $70.0 \%$ & [139] \\
\hline miR-6724-5p, miR-1185-1-3p and miR-6831-5p & Serum & $\uparrow$ & & & \\
\hline miR-6087, miR-3960 and miR-1343-5p & Serum & $\downarrow$ & $95.0 \%$ & $87.0 \%$ & [140] \\
\hline RNA ratio: $\mathrm{miR}-126 / \mathrm{miR}-152$ & Urine & - & $72.0 \%$ & $82.0 \%$ & [141] \\
\hline miR-21-5p & Urine & $\uparrow$ & $75.0 \%$ & $95.8 \%$ & [142] \\
\hline mir-21, miR-93, miR-200c and miR-940 & Urine & $\uparrow$ & $88.0 \%$ & $78.0 \%$ & [143] \\
\hline miR-652, miR-199a-3p, miR-140-5p, miR-93 and miR-142-5p & Urine & $\uparrow$ & $87 \%$ & $100 \%$ & [144] \\
\hline RNA ratio: miR-6124/miR-4511 & Urine & - & $>90.0 \%$ & - & [145] \\
\hline miR-99a and miR-125b & Urine & $\downarrow$ & $81.4 \%$ & $87.0 \%$ & [146] \\
\hline miR16, miR200c, miR205, miR21, miR221 and miR34a & Urine & $\uparrow$ & $88.0 \%$ & $48.0 \%$ & [147] \\
\hline
\end{tabular}

-: Unknown/Not applicable.

\section{Drug Targets and miRNA-Based Therapeutic Strategies}

Being involved in the development and progression of cancers of the urinary system, miRNAs potentially represent future therapeutic targets. Current research is deploying two main strategies to use miRNAs in cancer management: (1) replacement of down-regulated tumor suppressor miRNAs and (2) inhibition of up-regulated oncomiRs. However, these applications are facing several challenges, including validating delivery systems, selective cellular uptake by target cells, miRNA stability, off-target effects, and possible adverse reactions $[148,149]$. Several ongoing approaches to target OncomiRs are under investigation. These involve, for example, antisense miRNA inhibitors (also known as antagomirs), which bind specifically to the sense miRNA, leading to its degradation or deactivation [150]. To maintain the stability of antagomirs, locked nucleic acids are commonly attached to a phosphorothioate backbone [151,152]. Other strategies comprise miRNA sponges and MASK (miRNA-masking antisense oligonucleotides), which function via binding of complementary oligonucleotides to the possible binding sites of oncomiRs on mRNA [153, 154]. On the other hand, many miRNAs that are down-regulated in urologic cancers could have potential antitumor effects on growth and tumorigenesis. Consequently, clinicians and researchers are identifying and characterizing these tumor suppressor miRNAs and observing their biological roles. Techniques employed in restoring the activity of these miRNAs involve miRNA mimics as well as carriers, e.g., viral vectors and non-viral vectors, including inorganic compounds and lipid-based carriers [155,156].

\section{Conclusions}

As a result of the progressively increasing incidence of urinary tract cancers, scientists and clinicians are researching potential approaches and strategies to enhance the diag- 
nosis and management of these malignancies. The ability of miRNAs to modulate gene expression empowers them to alter tumor development and progression. Fortunately, the currently available literature indicates that miRNAs can be used as powerful tools, i.e., being used as diagnostic and/or prognostic markers in addition to therapeutic targets in urologic cancers. In this review, we discussed, using the available literature, the expression levels of various miRNAs in urinary tract cancers. Notably, most studies reported in this review examined levels of miRNAs in tumor tissues that were removed surgically before applying any treatment. Investigating serum or urinary miRNA level in patients undergoing, and subsequent to chemo- or radiotherapy, may provide an insight into the prognostic values of these molecules. Despite the immensity of clinical studies as well as both in vivo and in vitro experiments characterizing miRNA expression in kidney, upper tract, and bladder cancers, we still have not established many of their biological functions and possible targets. Therefore, further research identifying the role of these miRNAs in cancer development and their regulated pathways is recommended. Similarly, additional studies promoting miRNA delivery strategies and applications are still required to be used in clinical trials and future cancer therapies.

Author Contributions: Conceptualization, S.D., A.M.S.; writing—original draft preparation, A.M.S.; writing - review and editing, A.M.S., M.S., S.D., S.L.T. All authors have read and agreed to the published version of the manuscript.

Funding: This research received no external funding.

Conflicts of Interest: The authors declare no conflict of interest.

\section{References}

1. Li, P.; Znaor, A.; Holcatova, I.; Fabianova, E.; Mates, D.; Wozniak, M.B.; Ferlay, J.; Scelo, G. Regional Geographic Variations in Kidney Cancer Incidence Rates in European Countries. Eur. Urol. 2015, 67, 1134-1141. [CrossRef] [PubMed]

2. Ferlay, J.; Soerjomataram, I.; Dikshit, R.; Eser, S.; Mathers, C.; Rebelo, M.; Parkin, D.M.; Forman, D.; Bray, F. Cancer Incidence and Mortality Worldwide: Sources, Methods and Major Patterns in GLOBOCAN 2012. Int. J. Cancer 2015, 136, E359-E386. [CrossRef] [PubMed]

3. Ljungberg, B.; Campbell, S.C.; Choi, H.Y.; Cho, H.Y.; Jacqmin, D.; Lee, J.E.; Weikert, S.; Kiemeney, L.A. The Epidemiology of Renal Cell Carcinoma. Eur. Urol. 2011, 60, 615-621. [CrossRef] [PubMed]

4. Turajlic, S.; Swanton, C.; Boshoff, C. Kidney Cancer: The next Decade. J. Exp. Med. 2018, 215, 2477-2479. [CrossRef]

5. Gupta, K.; Miller, J.D.; Li, J.Z.; Russell, M.W.; Charbonneau, C. Epidemiologic and Socioeconomic Burden of Metastatic Renal Cell Carcinoma (MRCC): A Literature Review. Cancer Treat. Rev. 2008, 34, 193-205. [CrossRef]

6. Hall, M.C.; Chang, S.S.; Dalbagni, G.; Pruthi, R.S.; Seigne, J.D.; Skinner, E.C.; Wolf, J.S.; Schellhammer, P.F. Guideline for the Management of Nonmuscle Invasive Bladder Cancer (Stages Ta, T1, and Tis): 2007 Update. J. Urol. 2007, 178, $2314-2330$. [CrossRef]

7. Siegel, R.L.; Miller, K.D.; Jemal, A. Cancer Statistics, 2016. CA Cancer J. Clin. 2016, 66, 7-30. [CrossRef]

8. Antoni, S.; Ferlay, J.; Soerjomataram, I.; Znaor, A.; Jemal, A.; Bray, F. Bladder Cancer Incidence and Mortality: A Global Overview and Recent Trends. Eur. Urol. 2017, 71, 96-108. [CrossRef]

9. Torre, L.A.; Bray, F.; Siegel, R.L.; Ferlay, J.; Lortet-Tieulent, J.; Jemal, A. Global Cancer Statistics, 2012. CA Cancer J. Clin. 2015, 65, 87-108. [CrossRef]

10. Lee, R.C.; Feinbaum, R.L.; Ambros, V. The C. Elegans Heterochronic Gene Lin-4 Encodes Small RNAs with Antisense Complementarity to Lin-14. Cell 1993, 75, 843-854. [CrossRef]

11. Wightman, B.; Ha, I.; Ruvkun, G. Posttranscriptional Regulation of the Heterochronic Gene Lin-14 by Lin-4 Mediates Temporal Pattern Formation in C. elegans. Cell 1993, 75, 855-862. [CrossRef]

12. Bartel, D.P. MicroRNAs: Genomics, Biogenesis, Mechanism, and Function. Cell 2004, 116, 281-297. [CrossRef]

13. Bartel, D.P. MicroRNAs: Target Recognition and Regulatory Functions. Cell 2009, 136, 215-233. [CrossRef]

14. Soliman, A.M.; Das, S.; Abd Ghafar, N.; Teoh, S.L. Role of MicroRNA in Proliferation Phase of Wound Healing. Front. Genet. 2018, 9, 38. [CrossRef]

15. Anastasiadou, E.; Jacob, L.S.; Slack, F.J. Non-Coding RNA Networks in Cancer. Nat. Rev. Cancer 2018, 18, 5. [CrossRef]

16. Peng, Y.; Croce, C.M. The Role of MicroRNAs in Human Cancer. Signal Transduct. Target. Ther. 2016, 1, 1-9. [CrossRef] [PubMed]

17. Soliman, A.M.; Lin, T.S.; Mahakkanukrauh, P.; Das, S. Role of MicroRNAs in Diagnosis, Prognosis and Management of Multiple Myeloma. Int. J. Mol. Sci. 2020, 21, 7539. [CrossRef]

18. Soliman, A.M.; Das, S.; Teoh, S.L. Next-Generation Biomarkers in Multiple Myeloma: Understanding the Molecular Basis for Potential Use in Diagnosis and Prognosis. Int. J. Mol. Sci. 2021, 22, 7470. [CrossRef] [PubMed] 
19. Hao, N.-B.; He, Y.-F.; Li, X.-Q.; Wang, K.; Wang, R.-L. The Role of MiRNA and LncRNA in Gastric Cancer. Oncotarget 2017,8 , 81572. [CrossRef]

20. de Abreu, F.B.; Liu, X.; Tsongalis, G.J. MiRNA Analysis in Pancreatic Cancer: The Dartmouth Experience. Clin. Chem. Lab. Med. 2017, 55, 755-762. [CrossRef]

21. Balacescu, O.; Sur, D.; Cainap, C.; Visan, S.; Cruceriu, D.; Manzat-Saplacan, R.; Muresan, M.-S.; Balacescu, L.; Lisencu, C.; Irimie, A. The Impact of MiRNA in Colorectal Cancer Progression and Its Liver Metastases. Int. J. Mol. Sci. 2018, 19, 3711. [CrossRef] [PubMed]

22. Kulkarni, B.; Kirave, P.; Gondaliya, P.; Jash, K.; Jain, A.; Tekade, R.K.; Kalia, K. Exosomal MiRNA in Chemoresistance, Immune Evasion, Metastasis and Progression of Cancer. Drug Discov. Today 2019, 24, 2058-2067. [CrossRef]

23. Svoronos, A.A.; Engelman, D.M.; Slack, F.J. OncomiR or Tumor Suppressor? The Duplicity of MicroRNAs in Cancer. Cancer Res. 2016, 76, 3666-3670. [CrossRef]

24. Xu, L.; Yang, B.-F.; Ai, J. MicroRNA Transport: A New Way in Cell Communication. J. Cell Physiol. 2013, 228, 1713-1719. [CrossRef] [PubMed]

25. Wang, K.; Zhang, S.; Weber, J.; Baxter, D.; Galas, D.J. Export of MicroRNAs and MicroRNA-Protective Protein by Mammalian Cells. Nucleic Acids Res. 2010, 38, 7248-7259. [CrossRef] [PubMed]

26. Gong, J.; Jaiswal, R.; Mathys, J.M.; Combes, V.; Grau, G.E.R.; Bebawy, M. Microparticles and Their Emerging Role in Cancer Multidrug Resistance. Cancer Treat. Rev. 2012, 38, 226-234. [CrossRef]

27. Cui, M.; Wang, H.; Yao, X.; Zhang, D.; Xie, Y.; Cui, R.; Zhang, X. Circulating MicroRNAs in Cancer: Potential and Challenge. Front. Genet. 2019, 10, 626. [CrossRef]

28. Hayes, J.; Peruzzi, P.P.; Lawler, S. MicroRNAs in Cancer: Biomarkers, Functions and Therapy. Trends Mol. Med. 2014, 20, 460-469. [CrossRef]

29. Nakada, C.; Matsuura, K.; Tsukamoto, Y.; Tanigawa, M.; Yoshimoto, T.; Narimatsu, T.; Nguyen, L.T.; Hijiya, N.; Uchida, T.; Sato, F.; et al. Genome-Wide MicroRNA Expression Profiling in Renal Cell Carcinoma: Significant down-Regulation of MiR-141 and MiR-200c. J. Pathol. 2008, 216, 418-427. [CrossRef]

30. Park, S.-M.; Gaur, A.B.; Lengyel, E.; Peter, M.E. The MiR-200 Family Determines the Epithelial Phenotype of Cancer Cells by Targeting the E-Cadherin Repressors ZEB1 and ZEB2. Genes Dev. 2008, 22, 894-907. [CrossRef]

31. Yun, S.J.; Kim, W.-J. Role of the Epithelial-Mesenchymal Transition in Bladder Cancer: From Prognosis to Therapeutic Target. Korean J. Urol. 2013, 54, 645-650. [CrossRef]

32. Dutta, K.K.; Zhong, Y.; Liu, Y.-T.; Yamada, T.; Akatsuka, S.; Hu, Q.; Yoshihara, M.; Ohara, H.; Takehashi, M.; Shinohara, T.; et al. Association of MicroRNA-34a Overexpression with Proliferation Is Cell Type-Dependent. Cancer Sci. 2007, 98, 1845-1852. [CrossRef] [PubMed]

33. Juan, D.; Alexe, G.; Antes, T.; Liu, H.; Madabhushi, A.; Delisi, C.; Ganesan, S.; Bhanot, G.; Liou, L.S. Identification of a MicroRNA Panel for Clear-Cell Kidney Cancer. Urology 2010, 75, 835-841. [CrossRef] [PubMed]

34. Huang, Y.; Dai, Y.; Yang, J.; Chen, T.; Yin, Y.; Tang, M.; Hu, C.; Zhang, L. Microarray Analysis of MicroRNA Expression in Renal Clear Cell Carcinoma. Eur. J. Surg. Oncol. 2009, 35, 1119-1123. [CrossRef] [PubMed]

35. Petillo, D.; Kort, E.J.; Anema, J.; Furge, K.A.; Yang, X.J.; Teh, B.T. MicroRNA Profiling of Human Kidney Cancer Subtypes. Int. J. Oncol. 2009, 35, 109-114. [CrossRef] [PubMed]

36. Liang, T.; Hu, X.-Y.; Li, Y.-H.; Tian, B.-Q.; Li, Z.-W.; Fu, Q. MicroRNA-21 Regulates the Proliferation, Differentiation, and Apoptosis of Human Renal Cell Carcinoma Cells by the MTOR-STAT3 Signaling Pathway. Oncol. Res. 2016, 24, 371-380. [CrossRef]

37. Toraih, E.A.; Ibrahiem, A.T.; Fawzy, M.S.; Hussein, M.H.; Al-Qahtani, S.A.M.; Shaalan, A.A.M. MicroRNA-34a: A Key Regulator in the Hallmarks of Renal Cell Carcinoma. Oxidative Med. Cell Longev. 2017, 2017, 3269379. [CrossRef]

38. Wu, D.; Niu, X.; Pan, H.; Zhou, Y.; Zhang, Z.; Qu, P.; Zhou, J. Tumor-suppressing Effects of MicroRNA-429 in Human Renal Cell Carcinoma via the Downregulation of Sp1. Oncol. Lett. 2016, 12, 2906-2911. [CrossRef]

39. Zhang, J.; Ye, Y.; Chang, D.W.; Lin, S.-H.; Huang, M.; Tannir, N.M.; Matin, S.; Karam, J.A.; Wood, C.G.; Chen, Z.-N.; et al. Global and Targeted MiRNA Expression Profiling in Clear Cell Renal Cell Carcinoma Tissues Potentially Links MiR-155-5p and MiR-210-3p to Both Tumorigenesis and Recurrence. Am. J. Pathol. 2018, 188, 2487-2496. [CrossRef]

40. Li, Y.; Chen, D.; Su, Z.; Li, Y.; Liu, J.; Jin, L.; Shi, M.; Jiang, Z.; Qi, Z.; Gui, Y.; et al. MicroRNA-106b Functions as an Oncogene in Renal Cell Carcinoma by Affecting Cell Proliferation, Migration and Apoptosis. Mol. Med. Rep. 2016, 13, 1420-1426. [CrossRef]

41. Xiao, H.; Xiao, W.; Cao, J.; Li, H.; Guan, W.; Guo, X.; Chen, K.; Zheng, T.; Ye, Z.; Wang, J.; et al. MiR-206 Functions as a Novel Cell Cycle Regulator and Tumor Suppressor in Clear-Cell Renal Cell Carcinoma. Cancer Lett. 2016, 374, 107-116. [CrossRef] [PubMed]

42. Fan, W.; Huang, J.; Xiao, H.; Liang, Z. MicroRNA-22 Is Downregulated in Clear Cell Renal Cell Carcinoma, and Inhibits Cell Growth, Migration and Invasion by Targeting PTEN. Mol. Med. Rep. 2016, 13, 4800-4806. [CrossRef]

43. Chen, Z.; Zhang, J.; Zhang, Z.; Feng, Z.; Wei, J.; Lu, J.; Fang, Y.; Liang, Y.; Cen, J.; Pan, Y.; et al. The Putative Tumor Suppressor MicroRNA-30a-5p Modulates Clear Cell Renal Cell Carcinoma Aggressiveness through Repression of ZEB2. Cell Death Dis. 2017, 8, e2859. [CrossRef]

44. Szabó, Z.; Szegedi, K.; Gombos, K.; Mahua, C.; Flaskó, T.; Harda, K.; Halmos, G. Expression of MiRNA-21 and MiRNA-221 in Clear Cell Renal Cell Carcinoma (CcRCC) and Their Possible Role in the Development of CcRCC. Urol. Oncol. Semin. Orig. Investig. 2016, 34, 533.e21-533.e27. [CrossRef] 
45. Wang, W.; Hu, W.; Wang, Y.; Yang, J.; Yue, Z. MicroRNA-508 Is Downregulated in Clear Cell Renal Cell Carcinoma and Targets ZEB1 to Suppress Cell Proliferation and Invasion. Exp. Ther. Med. 2019, 17, 3814-3822. [CrossRef] [PubMed]

46. Yan, L.; Wu, K.; Du, F.; Yin, X.; Guan, H. MiR-384 Suppressed Renal Cell Carcinoma Cell Proliferation and Migration through Targeting RAB23. J. Cell Bioch. 2019, 120, 1420-1426. [CrossRef] [PubMed]

47. Liu, Y.; Qi, L.; Zhang, K.; Wang, F. MicroRNA-10a Suppresses Cell Metastasis by Targeting BDNF and Predicted Patients Survival in Renal Cell Carcinoma. J. BUON 2021, 26, 250-258. [PubMed]

48. Arai, T.; Okato, A.; Kojima, S.; Idichi, T.; Koshizuka, K.; Kurozumi, A.; Kato, M.; Yamazaki, K.; Ishida, Y.; Naya, Y.; et al. Regulation of Spindle and Kinetochore-Associated Protein 1 by Antitumor MiR-10a-5p in Renal Cell Carcinoma. Cancer Sci. 2017, 108, 2088-2101. [CrossRef]

49. Yamada, Y.; Arai, T.; Kato, M.; Kojima, S.; Sakamoto, S.; Komiya, A.; Naya, Y.; Ichikawa, T.; Seki, N. Role of Pre-MiR-532 (MiR-532-5p and MiR-532-3p) in Regulation of Gene Expression and Molecular Pathogenesis in Renal Cell Carcinoma. Am. J. Clin. Exp. Urol. 2019, 7, 11-30.

50. Yamada, Y.; Nohata, N.; Uchida, A.; Kato, M.; Arai, T.; Moriya, S.; Mizuno, K.; Kojima, S.; Yamazaki, K.; Naya, Y.; et al. Replisome Genes Regulation by Antitumor MiR-101-5p in Clear Cell Renal Cell Carcinoma. Cancer Sci. 2020, 111, 1392-1406. [CrossRef]

51. Okato, A.; Arai, T.; Yamada, Y.; Sugawara, S.; Koshizuka, K.; Fujimura, L.; Kurozumi, A.; Kato, M.; Kojima, S.; Naya, Y.; et al. Dual Strands of Pre-MiR-149 Inhibit Cancer Cell Migration and Invasion through Targeting FOXM1 in Renal Cell Carcinoma. Int. J. Mol. Sci. 2017, 18, 1969. [CrossRef]

52. Niu, S.; Ma, X.; Zhang, Y.; Liu, Y.-N.; Chen, X.; Gong, H.; Yao, Y.; Liu, K.; Zhang, X. MicroRNA-19a and MicroRNA-19b Promote the Malignancy of Clear Cell Renal Cell Carcinoma through Targeting the Tumor Suppressor RhoB. PLoS ONE 2018, 13, e0192790. [CrossRef] [PubMed]

53. Yamada, Y.; Arai, T.; Sugawara, S.; Okato, A.; Kato, M.; Kojima, S.; Yamazaki, K.; Naya, Y.; Ichikawa, T.; Seki, N. Impact of Novel Oncogenic Pathways Regulated by Antitumor MiR-451a in Renal Cell Carcinoma. Cancer Sci. 2018, 109, 1239-1253. [CrossRef] [PubMed]

54. Li, Y.; Li, J.; Sun, X.; Chen, J.; Sun, X.; Zheng, J.; Chen, R. MicroRNA-27a Functions as a Tumor Suppressor in Renal Cell Carcinoma by Targeting Epidermal Growth Factor Receptor. Oncol. Lett. 2016, 11, 4217-4223. [CrossRef]

55. Li, Y.; Chen, D.; Jin, L.; Liu, J.; Su, Z.; Li, Y.; Gui, Y.; Lai, Y. MicroRNA-20b-5p Functions as a Tumor Suppressor in Renal Cell Carcinoma by Regulating Cellular Proliferation, Migration and Apoptosis. Mol. Med. Rep. 2016, 13, 1895-1901. [CrossRef] [PubMed]

56. Wang, H.; Li, Z.-Y.; Xu, Z.-H.; Chen, Y.-L.; Lu, Z.-Y.; Shen, D.-Y.; Lu, J.-Y.; Zheng, Q.-M.; Wang, L.-Y.; Xu, L.-W.; et al. The Prognostic Value of MiRNA-18a-5p in Clear Cell Renal Cell Carcinoma and Its Function via the MiRNA-18a-5p/HIF1A/PVT1 Pathway. J. Cancer 2020, 11, 2737-2748. [CrossRef]

57. Pan, Y.-J.; Wei, L.-L.; Wu, X.-J.; Huo, F.-C.; Mou, J.; Pei, D.-S. MiR-106a-5p Inhibits the Cell Migration and Invasion of Renal Cell Carcinoma through Targeting PAK5. Cell Death Dis. 2017, 8, e3155. [CrossRef]

58. Yang, F.; Ma, J.; Tang, Q.; Zhang, W.; Fu, Q.; Sun, J.; Wang, H.; Song, B. MicroRNA-543 Promotes the Proliferation and Invasion of Clear Cell Renal Cell Carcinoma Cells by Targeting Krüppel-like Factor 6. Biomed. Pharm. 2018, 97, 616-623. [CrossRef]

59. Gilyazova, I.R.; Klimentova, E.A.; Bulygin, K.V.; Izmailov, A.A.; Bermisheva, M.A.; Galimova, E.F.; Safiullin, R.I.; Galimov, S.N.; Pavlov, V.N.; Khusnutdinova, E.K. MicroRNA-200 Family Expression Analysis in Metastatic Clear Cell Renal Cell Carcinoma Patients. Cancer Gene Ther. 2020, 27, 768-772. [CrossRef]

60. Fu, H.; Song, W.; Chen, X.; Guo, T.; Duan, B.; Wang, X.; Tang, Y.; Huang, L.; Zhang, C. MiRNA-200a Induce Cell Apoptosis in Renal Cell Carcinoma by Directly Targeting SIRT1. Mol. Cell Biochem. 2018, 437, 143-152. [CrossRef]

61. Wang, X.; Jiang, F.; Song, H.; Li, X.; Xian, J.; Gu, X. MicroRNA-200a-3p Suppresses Tumor Proliferation and Induces Apoptosis by Targeting SPAG9 in Renal Cell Carcinoma. Biochem. Biophys. Res. Commun. 2016, 470, 620-626. [CrossRef] [PubMed]

62. Wang, D.; Zhu, C.; Zhang, Y.; Zheng, Y.; Ma, F.; Su, L.; Shao, G. MicroRNA-30e-3p Inhibits Cell Invasion and Migration in Clear Cell Renal Cell Carcinoma by Targeting Snail1. Oncol. Lett. 2017, 13, 2053-2058. [CrossRef]

63. Goto, Y.; Kurozumi, A.; Nohata, N.; Kojima, S.; Matsushita, R.; Yoshino, H.; Yamazaki, K.; Ishida, Y.; Ichikawa, T.; Naya, Y.; et al. The MicroRNA Signature of Patients with Sunitinib Failure: Regulation of UHRF1 Pathways by MicroRNA-101 in Renal Cell Carcinoma. Oncotarget 2016, 7, 59070-59086. [CrossRef] [PubMed]

64. Würdinger, T.; Tannous, B.A.; Saydam, O.; Skog, J.; Grau, S.; Soutschek, J.; Weissleder, R.; Breakefield, X.O.; Krichevsky, A.M. MiR-296 Regulates Growth Factor Receptor Overexpression in Angiogenic Endothelial Cells. Cancer Cell 2008, 14, $382-393$. [CrossRef]

65. Sinha, S.; Dutta, S.; Datta, K.; Ghosh, A.K.; Mukhopadhyay, D. Von Hippel-Lindau Gene Product Modulates TIS11B Expression in Renal Cell Carcinoma: Impact on Vascular Endothelial Growth Factor Expression in Hypoxia. J. Biol. Chem. 2009, 284, 32610-32618. [CrossRef] [PubMed]

66. Neal, C.S.; Michael, M.Z.; Rawlings, L.H.; Van der Hoek, M.B.; Gleadle, J.M. The VHL-Dependent Regulation of MicroRNAs in Renal Cancer. BMC Med. 2010, 8, 64. [CrossRef] [PubMed]

67. Chan, S.Y.; Zhang, Y.-Y.; Hemann, C.; Mahoney, C.E.; Zweier, J.L.; Loscalzo, J. MicroRNA-210 Controls Mitochondrial Metabolism during Hypoxia by Repressing the Iron-Sulfur Cluster Assembly Proteins ISCU1/2. Cell Metab. 2009, 10, 273-284. [CrossRef] [PubMed] 
68. Liu, W.; Zabirnyk, O.; Wang, H.; Shiao, Y.-H.; Nickerson, M.L.; Khalil, S.; Anderson, L.M.; Perantoni, A.O.; Phang, J.M. MiR-23b Targets Proline Oxidase, a Novel Tumor Suppressor Protein in Renal Cancer. Oncogene 2010, 29, 4914-4924. [CrossRef]

69. Jiang, Z.; Chu, P.G.; Woda, B.A.; Liu, Q.; Balaji, K.C.; Rock, K.L.; Wu, C.-L. Combination of Quantitative IMP3 and Tumor Stage: A New System to Predict Metastasis for Patients with Localized Renal Cell Carcinomas. Clin. Cancer Res. 2008, 14, 5579-5584. [CrossRef]

70. Kassouf, W.; Monteiro, L.L.; Drachenberg, D.E.; Fairey, A.S.; Finelli, A.; Kapoor, A.; Lattouf, J.-B.; Leveridge, M.J.; Power, N.E.; Pouliot, F; i et al. Canadian Urological Association Guideline for Followup of Patients after Treatment of Non-Metastatic Renal Cell Carcinoma. Can. Urol. Assoc. J. 2018, 12, 231-238. [CrossRef]

71. Choueiri, T.K.; Motzer, R.J. Systemic Therapy for Metastatic Renal-Cell Carcinoma. N. Engl. J. Med. 2017, 376, 354-366. [CrossRef] [PubMed]

72. Oldenhuis, C.N.A.M.; Oosting, S.F.; Gietema, J.A.; de Vries, E.G.E. Prognostic versus Predictive Value of Biomarkers in Oncology. Eur. J. Cancer 2008, 44, 946-953. [CrossRef]

73. Cannistra, S.A. When Is a "Prognostic Factor" Really Prognostic? J. Clin. Oncol. 2000, 18, 3745-3747. [CrossRef]

74. Li, H.; Samawi, H.; Heng, D.Y.C. The Use of Prognostic Factors in Metastatic Renal Cell Carcinoma. Urol. Oncol. 2015, 33, 509-516. [CrossRef]

75. Motzer, R.J.; Mazumdar, M.; Bacik, J.; Berg, W.; Amsterdam, A.; Ferrara, J. Survival and Prognostic Stratification of 670 Patients with Advanced Renal Cell Carcinoma. J. Clin. Oncol. 1999, 17, 2530-2540. [CrossRef]

76. Rini, B.I.; Campbell, S.C.; Escudier, B. Renal Cell Carcinoma. Lancet 2009, 373, 1119-1132. [CrossRef]

77. Zisman, A.; Pantuck, A.J.; Figlin, R.A.; Belldegrun, A.S. Validation of the Ucla Integrated Staging System for Patients with Renal Cell Carcinoma. J. Clin. Oncol. 2001, 19, 3792-3793. [CrossRef] [PubMed]

78. Teixeira, A.L.; Dias, F.; Ferreira, M.; Gomes, M.; Santos, J.I.; Lobo, F.; Maurício, J.; Machado, J.C.; Medeiros, R. Combined Influence of EGF+61G $>$ A and TGFB+869T >C Functional Polymorphisms in Renal Cell Carcinoma Progression and Overall Survival: The Link to Plasma Circulating MiR-7 and MiR-221/222 Expression. PLoS ONE 2015, 10, e0103258. [CrossRef]

79. Malouf, G.G.; Su, X.; Yao, H.; Gao, J.; Xiong, L.; He, Q.; Compérat, E.; Couturier, J.; Molinié, V.; Escudier, B.; et al. NextGeneration Sequencing of Translocation Renal Cell Carcinoma Reveals Novel RNA Splicing Partners and Frequent Mutations of Chromatin-Remodeling Genes. Clin. Cancer Res. 2014, 20, 4129-4140. [CrossRef] [PubMed]

80. Dimitrieva, S.; Schlapbach, R.; Rehrauer, H. Prognostic Value of Cross-Omics Screening for Kidney Clear Cell Renal Cancer Survival. Biol. Direct 2016, 11, 68. [CrossRef]

81. Mitchell, P.S.; Parkin, R.K.; Kroh, E.M.; Fritz, B.R.; Wyman, S.K.; Pogosova-Agadjanyan, E.L.; Peterson, A.; Noteboom, J.; O'Briant, K.C.; Allen, A.; et al. Circulating MicroRNAs as Stable Blood-Based Markers for Cancer Detection. Proc. Natl. Acad. Sci. USA 2008, 105, 10513-10518. [CrossRef]

82. Turchinovich, A.; Weiz, L.; Langheinz, A.; Burwinkel, B. Characterization of Extracellular Circulating MicroRNA. Nucleic Acids Res. 2011, 39, 7223-7233. [CrossRef]

83. Kosaka, N.; Iguchi, H.; Ochiya, T. Circulating MicroRNA in Body Fluid: A New Potential Biomarker for Cancer Diagnosis and Prognosis. Cancer Sci. 2010, 101, 2087-2092. [CrossRef]

84. Du, M.; Giridhar, K.V.; Tian, Y.; Tschannen, M.R.; Zhu, J.; Huang, C.-C.; Kilari, D.; Kohli, M.; Wang, L. Plasma Exosomal MiRNAs-Based Prognosis in Metastatic Kidney Cancer. Oncotarget 2017, 8, 63703-63714. [CrossRef]

85. Lou, N.; Ruan, A.-M.; Qiu, B.; Bao, L.; Xu, Y.-C.; Zhao, Y.; Sun, R.-L.; Zhang, S.-T.; Xu, G.-H.; Ruan, H.-L.; et al. MiR-144-3p as a Novel Plasma Diagnostic Biomarker for Clear Cell Renal Cell Carcinoma. Urol. Oncol. Semin. Orig. Investig. 2017, 35, 36.e7-36.e14. [CrossRef]

86. Wang, X.; Wang, T.; Chen, C.; Wu, Z.; Bai, P.; Li, S.; Chen, B.; Liu, R.; Zhang, K.; Li, W.; et al. Serum Exosomal MiR-210 as a Potential Biomarker for Clear Cell Renal Cell Carcinoma. J. Cell BioChem 2019, 120, 1492-1502. [CrossRef] [PubMed]

87. Teixeira, A.L.; Ferreira, M.; Silva, J.; Gomes, M.; Dias, F.; Santos, J.I.; Maurício, J.; Lobo, F.; Medeiros, R. Higher Circulating Expression Levels of MiR-221 Associated with Poor Overall Survival in Renal Cell Carcinoma Patients. Tumour Biol. 2014, 35, 4057-4066. [CrossRef] [PubMed]

88. Heinemann, F.G.; Tolkach, Y.; Deng, M.; Schmidt, D.; Perner, S.; Kristiansen, G.; Müller, S.C.; Ellinger, J. Serum MiR-122-5p and MiR-206 Expression: Non-Invasive Prognostic Biomarkers for Renal Cell Carcinoma. Clin. Epigenetics 2018, 10, 11. [CrossRef] [PubMed]

89. Zhang, W.; Ni, M.; Su, Y.; Wang, H.; Zhu, S.; Zhao, A.; Li, G. MicroRNAs in Serum Exosomes as Potential Biomarkers in Clear-Cell Renal Cell Carcinoma. Eur. Urol. Focus 2018, 4, 412-419. [CrossRef]

90. Song, S.; Long, M.; Yu, G.; Cheng, Y.; Yang, Q.; Liu, J.; Wang, Y.; Sheng, J.; Wang, L.; Wang, Z.; et al. Urinary Exosome MiR-30c-5p as a Biomarker of Clear Cell Renal Cell Carcinoma That Inhibits Progression by Targeting HSPA5. J. Cell Mol. Med. 2019, 23, 6755-6765. [CrossRef]

91. Fedorko, M.; Juracek, J.; Stanik, M.; Svoboda, M.; Poprach, A.; Buchler, T.; Pacik, D.; Dolezel, J.; Slaby, O. Detection of Let-7 MiRNAs in Urine Supernatant as Potential Diagnostic Approach in Non-Metastatic Clear-Cell Renal Cell Carcinoma. Biochem. Med. 2017, 27, 411-417. [CrossRef]

92. Exosomal MicroRNAs Are Diagnostic Biomarkers and Can Mediate Cell-Cell Communication in Renal Cell Carcinoma. Eur. Urol. Focus 2016, 2, 210-218. [CrossRef] 
93. Li, G.; Zhao, A.; Péoch, M.; Cottier, M.; Mottet, N. Detection of Urinary Cell-Free MiR-210 as a Potential Tool of Liquid Biopsy for Clear Cell Renal Cell Carcinoma. Urol. Oncol. Semin. Orig. Investig. 2017, 35, 294-299. [CrossRef]

94. Rouprêt, M.; Babjuk, M.; Compérat, E.; Zigeuner, R.; Sylvester, R.J.; Burger, M.; Cowan, N.C.; Gontero, P.; Van Rhijn, B.W.G.; Mostafid, A.H.; et al. European Association of Urology Guidelines on Upper Urinary Tract Urothelial Carcinoma: 2017 Update. Eur. Urol. 2018, 73, 111-122. [CrossRef]

95. Seisen, T.; Peyronnet, B.; Dominguez-Escrig, J.L.; Bruins, H.M.; Yuan, C.Y.; Babjuk, M.; Böhle, A.; Burger, M.; Compérat, E.M.; Cowan, N.C.; et al. Oncologic Outcomes of Kidney-Sparing Surgery Versus Radical Nephroureterectomy for Upper Tract Urothelial Carcinoma: A Systematic Review by the EAU Non-Muscle Invasive Bladder Cancer Guidelines Panel. Eur. Urol. 2016, 70, 1052-1068. [CrossRef] [PubMed]

96. Browne, B.M.; Stensland, K.D.; Moynihan, M.J.; Canes, D. An Analysis of Staging and Treatment Trends for Upper Tract Urothelial Carcinoma in the National Cancer Database. Clin. Genitourin Cancer 2018, 16, e743-e750. [CrossRef] [PubMed]

97. Browne, B.M.; Stensland, K.D.; Patel, C.K.; Sullivan, T.; Burks, E.J.; Canes, D.; Raman, J.D.; Warrick, J.; Reiger-Christ, K.M. MicroRNA Expression Profiles in Upper Tract Urothelial Carcinoma Differentiate Tumor Grade, Stage, and Survival: Implications for Clinical Decision-Making. Urology 2019, 123, 93-100. [CrossRef]

98. Tao, J.; Yang, X.; Li, P.; Wei, J.; Deng, X.; Cheng, Y.; Qin, C.; Ju, X.; Meng, X.; Li, J.; et al. Identification of Circulating MicroRNA Signatures for Upper Tract Urothelial Carcinoma Detection. Mol. Med. Rep. 2015, 12, 6752-6760. [CrossRef]

99. Zaravinos, A.; Lambrou, G.I.; Mourmouras, N.; Katafygiotis, P.; Papagregoriou, G.; Giannikou, K.; Delakas, D.; Deltas, C. New MiRNA Profiles Accurately Distinguish Renal Cell Carcinomas and Upper Tract Urothelial Carcinomas from the Normal Kidney. PLoS ONE 2014, 9, e91646. [CrossRef] [PubMed]

100. Chung, Y.-H.; Li, S.-C.; Kao, Y.-H.; Luo, H.-L.; Cheng, Y.-T.; Lin, P.-R.; Tai, M.-H.; Chiang, P.-H. MiR-30a-5p Inhibits Epithelialto-Mesenchymal Transition and Upregulates Expression of Tight Junction Protein Claudin-5 in Human Upper Tract Urothelial Carcinoma Cells. Int. J. Mol. Sci. 2017, 18, 1826. [CrossRef]

101. Popovska-Jankovic, K.; Noveski, P.; Jankovic-Velickovic, L.; Stojnev, S.; Cukuranovic, R.; Stefanovic, V.; Toncheva, D.; Staneva, R.; Polenakovic, M.; Plaseska-Karanfilska, D. MicroRNA Profiling in Patients with Upper Tract Urothelial Carcinoma Associated with Balkan Endemic Nephropathy. BioMed Res. Int. 2016, 2016, 7450461. [CrossRef] [PubMed]

102. Tao, L.; Zeng, Y.; Wang, J.; Liu, Z.; Shen, B.; Ge, J.; Liu, Y.; Guo, Y.; Qiu, J. Differential MicroRNA Expression in Aristolochic Acid-Induced Upper Urothelial Tract Cancers Ex Vivo. Mol. Med. Rep. 2015, 12, 6533-6546. [CrossRef] [PubMed]

103. Izquierdo, L.; Ingelmo-Torres, M.; Mallofré, C.; Lozano, J.J.; Verhasselt-Crinquette, M.; Leroy, X.; Colin, P.; Comperat, E.; Roupret, M.; Alcaraz, A.; et al. Prognostic Value of MicroRNA Expression Pattern in Upper Tract Urothelial Carcinoma. BJU Int. 2014, 113, 813-821. [CrossRef]

104. Ke, H.-L.; Li, W.-M.; Lin, H.-H.; Hsu, W.-C.; Hsu, Y.-L.; Chang, L.-L.; Huang, C.-N.; Li, C.-C.; Chang, H.-P.; Yeh, H.-C.; et al. Hypoxia-Regulated MicroRNA-210 Overexpression Is Associated with Tumor Development and Progression in Upper Tract Urothelial Carcinoma. Int. J. Med. Sci. 2017, 14, 578. [CrossRef]

105. Hsu, W.-C.; Li, W.-M.; Lee, Y.-C.; Huang, A.-M.; Chang, L.-L.; Lin, H.-H.; Wu, W.-J.; Li, C.-C.; Liang, P.-I.; Ke, H.-L. MicroRNA-145 Suppresses Cell Migration and Invasion in Upper Tract Urothelial Carcinoma by Targeting ARF6. FASEB J. 2020, 34, 5975-5992. [CrossRef] [PubMed]

106. Browne, B.; Patel, C.; Sullivan, T.; Burks, E.; Raman, J.; Warrick, J.; Canes, D. Rieger, -Christ Kimberly Pd13-02 Micro-Rna Expression Profiles in Upper Tract Urothelial Carcinoma Differentiate Grade and Stage: Implications for Clinical Decision Making. J. Urol. 2016, 195, e298. [CrossRef]

107. Gottardo, F.; Liu, C.G.; Ferracin, M.; Calin, G.A.; Fassan, M.; Bassi, P.; Sevignani, C.; Byrne, D.; Negrini, M.; Pagano, F.; et al. Micro-RNA Profiling in Kidney and Bladder Cancers. Urol. Oncol. 2007, 25, 387-392. [CrossRef]

108. Dyrskjøt, L.; Ostenfeld, M.S.; Bramsen, J.B.; Silahtaroglu, A.N.; Lamy, P.; Ramanathan, R.; Fristrup, N.; Jensen, J.L.; Andersen, C.L.; Zieger, K.; et al. Genomic Profiling of MicroRNAs in Bladder Cancer: MiR-129 Is Associated with Poor Outcome and Promotes Cell Death in Vitro. Cancer Res. 2009, 69, 4851-4860. [CrossRef]

109. Neely, L.A.; Rieger-Christ, K.M.; Neto, B.S.; Eroshkin, A.; Garver, J.; Patel, S.; Phung, N.A.; McLaughlin, S.; Libertino, J.A.; Whitney, D.; et al. A MicroRNA Expression Ratio Defining the Invasive Phenotype in Bladder Tumors. Urol. Oncol. 2010, 28 , 39-48. [CrossRef]

110. Catto, J.W.F.; Abbod, M.F.; Wild, P.J.; Linkens, D.A.; Pilarsky, C.; Rehman, I.; Rosario, D.J.; Denzinger, S.; Burger, M.; Stoehr, R.; et al. The Application of Artificial Intelligence to Microarray Data: Identification of a Novel Gene Signature to Identify Bladder Cancer Progression. Eur. Urol. 2010, 57, 398-406. [CrossRef]

111. Catto, J.W.F.; Miah, S.; Owen, H.C.; Bryant, H.; Myers, K.; Dudziec, E.; Larré, S.; Milo, M.; Rehman, I.; Rosario, D.J.; et al. Distinct MicroRNA Alterations Characterize High- and Low-Grade Bladder Cancer. Cancer Res. 2009, 69, 8472-8481. [CrossRef]

112. Yates, D.R.; Rehman, I.; Abbod, M.F.; Meuth, M.; Cross, S.S.; Linkens, D.A.; Hamdy, F.C.; Catto, J.W.F. Promoter Hypermethylation Identifies Progression Risk in Bladder Cancer. Clin. Cancer Res. 2007, 13, 2046-2053. [CrossRef] [PubMed]

113. Zhang, H.; Jiang, M.; Liu, Q.; Han, Z.; Zhao, Y.; Ji, S. MiR-145-5p Inhibits the Proliferation and Migration of Bladder Cancer Cells by Targeting TAGLN2. Oncol. Lett. 2018, 16, 6355-6360. [CrossRef] [PubMed]

114. Ganji, S.M.; Saidijam, M.; Amini, R.; Mousavi-Bahar, S.H.; Shabab, N.; Seyedabadi, S.; Mahdavinezhad, A. Evaluation of MicroRNA-99a and MicroRNA-205 Expression Levels in Bladder Cancer. Int. J. Mol. Cell Med. 2017, 6, 87-95. [CrossRef] 
115. Wei, Z.; Hu, X.; Liu, J.; Zhu, W.; Zhan, X.; Sun, S. MicroRNA-497 Upregulation Inhibits Cell Invasion and Metastasis in T24 and BIU-87 Bladder Cancer Cells. Mol. Med. Rep. 2017, 16, 2055-2060. [CrossRef] [PubMed]

116. Yuan, Q.; Sun, T.; Ye, F.; Kong, W.; Jin, H. MicroRNA-124-3p Affects Proliferation, Migration and Apoptosis of Bladder Cancer Cells through Targeting AURKA. Cancer Biomark. 2017, 19, 93-101. [CrossRef]

117. Wang, J.-R.; Liu, B.; Zhou, L.; Huang, Y.-X. MicroRNA-124-3p Suppresses Cell Migration and Invasion by Targeting ITGA3 Signaling in Bladder Cancer. Cancer Biomark. 2019, 24, 159-172. [CrossRef]

118. Liu, X.; Kong, C.; Zhang, Z. MiR-130b Promotes Bladder Cancer Cell Proliferation, Migration and Invasion by Targeting VGLL4. Oncol. Rep. 2018, 39, 2324-2332. [CrossRef]

119. He, X.; Ping, J.; Wen, D. MicroRNA-186 Regulates the Invasion and Metastasis of Bladder Cancer via Vascular Endothelial Growth Factor C. Exp. Ther. Med. 2017, 14, 3253-3258. [CrossRef]

120. Mao, X.-W.; Xiao, J.-Q.; Li, Z.-Y.; Zheng, Y.-C.; Zhang, N. Effects of MicroRNA-135a on the Epithelial-Mesenchymal Transition, Migration and Invasion of Bladder Cancer Cells by Targeting GSK3 $\beta$ through the Wnt/ $\beta$-Catenin Signaling Pathway. Exp. Mol. Med. 2018, 50, e429. [CrossRef]

121. Wang, W.; Shen, F.; Wang, C.; Lu, W.; Wei, J.; Shang, A.; Wang, C. MiR-1-3p Inhibits the Proliferation and Invasion of Bladder Cancer Cells by Suppressing CCL2 Expression. Tumour Biol. 2017, 39, 1010428317698383. [CrossRef] [PubMed]

122. Wang, Y.; Xu, Z.; Wang, X. MiRNA-373 Promotes Urinary Bladder Cancer Cell Proliferation, Migration and Invasion through Upregulating Epidermal Growth Factor Receptor. Exper Ther. Med. 2019, 17, 1190-1195. [CrossRef]

123. Liu, S.; Chen, Q.; Wang, Y. MiR-125b-5p Suppresses the Bladder Cancer Progression via Targeting HK2 and Suppressing PI3K/AKT Pathway. Hum. Cell 2020, 33, 185-194. [CrossRef]

124. Yan, T.; Ye, X.-X. MicroRNA-328-3p Inhibits the Tumorigenesis of Bladder Cancer through Targeting ITGA5 and Inactivating PI3K/AKT Pathway. Eur. Rev. Med. Pharm. Sci. 2019, 23, 5139-5148. [CrossRef]

125. Zhang, J.; Mao, S.; Wang, L.; Zhang, W.; Zhang, Z.; Guo, Y.; Wu, Y.; Yi, F.; Yao, X. MicroRNA-154 Functions as a Tumor Suppressor in Bladder Cancer by Directly Targeting ATG7. Oncol. Rep. 2019, 41, 819-828. [CrossRef] [PubMed]

126. Wang, W.; Ying, Y.; Xie, H.; Li, J.; Ma, X.; He, L.; Xu, M.; Chen, S.; Shen, H.; Zheng, X.; et al. MiR-665 Inhibits Epithelial-toMesenchymal Transition in Bladder Cancer via the SMAD3/SNAIL Axis. Cell Cycle 2021, 20, 1242-1252. [CrossRef]

127. Xie, X.; Pan, J.; Han, X.; Chen, W. Downregulation of MicroRNA-532-5p Promotes the Proliferation and Invasion of Bladder Cancer Cells through Promotion of HMGB3/Wnt/ $\beta$-Catenin Signaling. Chem.-Biol. Interact. 2019, 300, 73-81. [CrossRef]

128. Zhang, W.; Mao, S.; Shi, D.; Zhang, J.; Zhang, Z.; Guo, Y.; Wu, Y.; Wang, R.; Wang, L.; Huang, Y.; et al. MicroRNA-153 Decreases Tryptophan Catabolism and Inhibits Angiogenesis in Bladder Cancer by Targeting Indoleamine 2,3-Dioxygenase 1. Front. Oncol. 2019, 9, 619. [CrossRef] [PubMed]

129. Yan, H.; Li, J.; Ying, Y.; Xie, H.; Chen, H.; Xu, X.; Zheng, X. MIR-300 in the Imprinted DLK1-DIO3 Domain Suppresses the Migration of Bladder Cancer by Regulating the SP1/MMP9 Pathway. Cell Cycle 2018, 17, 2790-2801. [CrossRef] [PubMed]

130. Adam, L.; Zhong, M.; Choi, W.; Qi, W.; Nicoloso, M.; Arora, A.; Calin, G.; Wang, H.; Siefker-Radtke, A.; McConkey, D.; et al. MiR200 Expression Regulates Epithelial-to-Mesenchymal Transition in Bladder Cancer Cells and Reverses Resistance to Epidermal Growth Factor Receptor Therapy. Clin. Cancer Res. 2009, 15, 5060-5072. [CrossRef]

131. Wiklund, E.D.; Bramsen, J.B.; Hulf, T.; Dyrskjøt, L.; Ramanathan, R.; Hansen, T.B.; Villadsen, S.B.; Gao, S.; Ostenfeld, M.S.; Borre, M.; et al. Coordinated Epigenetic Repression of the MiR-200 Family and MiR-205 in Invasive Bladder Cancer. Int. J. Cancer 2011, 128, 1327-1334. [CrossRef] [PubMed]

132. Kenney, P.A.; Wszolek, M.F.; Rieger-Christ, K.M.; Neto, B.S.; Gould, J.J.; Harty, N.J.; Mosquera, J.M.; Zeheb, R.; Loda, M.; Darling, D.S.; et al. Novel ZEB1 Expression in Bladder Tumorigenesis. BJU Int. 2011, 107, 656-663. [CrossRef]

133. Burk, U.; Schubert, J.; Wellner, U.; Schmalhofer, O.; Vincan, E.; Spaderna, S.; Brabletz, T. A Reciprocal Repression between ZEB1 and Members of the MiR-200 Family Promotes EMT and Invasion in Cancer Cells. EMBO Rep. 2008, 9, 582-589. [CrossRef] [PubMed]

134. Yoshino, H.; Enokida, H.; Chiyomaru, T.; Tatarano, S.; Hidaka, H.; Yamasaki, T.; Gotannda, T.; Tachiwada, T.; Nohata, N.; Yamane, T. Tumor Suppressive MicroRNA-1 Mediated Novel Apoptosis Pathways through Direct Inhibition of Splicing Factor Serine/Arginine-Rich 9 (SRSF9/SRp30c) in Bladder Cancer. BioChem Biophys. Res. Commun. 2012, 417, 588-593. [CrossRef]

135. Matsushita, R.; Seki, N.; Chiyomaru, T.; Inoguchi, S.; Ishihara, T.; Goto, Y.; Nishikawa, R.; Mataki, H.; Tatarano, S.; Itesako, T.; et al. Tumour-Suppressive MicroRNA-144-5p Directly Targets CCNE1/2 as Potential Prognostic Markers in Bladder Cancer. Br. J. Cancer 2015, 113, 282-289. [CrossRef]

136. Chiyomaru, T.; Enokida, H.; Tatarano, S.; Kawahara, K.; Uchida, Y.; Nishiyama, K.; Fujimura, L.; Kikkawa, N.; Seki, N.; Nakagawa, M. MiR-145 and MiR-133a Function as Tumour Suppressors and Directly Regulate FSCN1 Expression in Bladder Cancer. Br. J. Cancer 2010, 102, 883-891. [CrossRef]

137. Chiyomaru, T.; Enokida, H.; Kawakami, K.; Tatarano, S.; Uchida, Y.; Kawahara, K.; Nishiyama, K.; Seki, N.; Nakagawa, M. Functional Role of LASP1 in Cell Viability and Its Regulation by MicroRNAs in Bladder Cancer. Urol. Oncol. 2012, $30,434-443$. [CrossRef] [PubMed]

138. Chen, M.F.; Zeng, F.; Qi, L.; Zu, X.B.; Wang, J.; Liu, L.F.; Li, Y. Transforming Growth Factor- $\beta 1$ Induces Epithelial-mesenchymal Transition and Increased Expression of Matrix Metalloproteinase-16 via MiR-200b Downregulation in Bladder Cancer Cells. Mol. Med. Rep. 2014, 10, 1549-1554. [CrossRef] 
139. Jiang, X.; Du, L.; Duan, W.; Wang, R.; Yan, K.; Wang, L.; Li, J.; Zheng, G.; Zhang, X.; Yang, Y.; et al. Serum MicroRNA Expression Signatures as Novel Noninvasive Biomarkers for Prediction and Prognosis of Muscle-Invasive Bladder Cancer. Oncotarget 2016, 7, 36733-36742. [CrossRef]

140. Usuba, W.; Urabe, F.; Yamamoto, Y.; Matsuzaki, J.; Sasaki, H.; Ichikawa, M.; Takizawa, S.; Aoki, Y.; Niida, S.; Kato, K.; et al. Circulating MiRNA Panels for Specific and Early Detection in Bladder Cancer. Cancer Sci. 2019, 110, 408-419. [CrossRef]

141. Hanke, M.; Hoefig, K.; Merz, H.; Feller, A.C.; Kausch, I.; Jocham, D.; Warnecke, J.M.; Sczakiel, G. A Robust Methodology to Study Urine MicroRNA as Tumor Marker: MicroRNA-126 and MicroRNA-182 Are Related to Urinary Bladder Cancer. Urol. Oncol. Semin. Orig. Investig. 2010, 28, 655-661. [CrossRef] [PubMed]

142. Matsuzaki, K.; Fujita, K.; Jingushi, K.; Kawashima, A.; Ujike, T.; Nagahara, A.; Ueda, Y.; Tanigawa, G.; Yoshioka, I.; Ueda, K.; et al. MiR-21-5p in Urinary Extracellular Vesicles Is a Novel Biomarker of Urothelial Carcinoma. Oncotarget 2017, 8, 24668-24678. [CrossRef] [PubMed]

143. Long, J.D.; Sullivan, T.B.; Humphrey, J.; Logvinenko, T.; Summerhayes, K.A.; Kozinn, S.; Harty, N.; Summerhayes, I.C.; Libertino, J.A.; Holway, A.H.; et al. A Non-Invasive MiRNA Based Assay to Detect Bladder Cancer in Cell-Free Urine. Am. J. Transl Res. 2015, 7, 2500-2509. [PubMed]

144. Urquidi, V.; Netherton, M.; Gomes-Giacoia, E.; Serie, D.J.; Eckel-Passow, J.; Rosser, C.J.; Goodison, S. A MicroRNA Biomarker Panel for the Non-Invasive Detection of Bladder Cancer. Oncotarget 2016, 7, 86290-86299. [CrossRef]

145. Piao, X.-M.; Jeong, P.; Kim, Y.-H.; Byun, Y.J.; Xu, Y.; Kang, H.W.; Ha, Y.-S.; Kim, W.T.; Lee, J.-Y.; Woo, S.H.; et al. Urinary Cell-Free MicroRNA Biomarker Could Discriminate Bladder Cancer from Benign Hematuria. Int. J. Cancer 2019, 144, 380-388. [CrossRef]

146. Zhang, D.-Z.; Lau, K.-M.; Chan, E.S.Y.; Wang, G.; Szeto, C.-C.; Wong, K.; Choy, R.K.W.; Ng, C.-F. Cell-Free Urinary MicroRNA-99a and MicroRNA-125b Are Diagnostic Markers for the Non-Invasive Screening of Bladder Cancer. PLoS ONE 2014, 9, e100793. [CrossRef] [PubMed]

147. Sapre, N.; Macintyre, G.; Clarkson, M.; Naeem, H.; Cmero, M.; Kowalczyk, A.; Anderson, P.D.; Costello, A.J.; Corcoran, N.M.; Hovens, C.M. A Urinary MicroRNA Signature Can Predict the Presence of Bladder Urothelial Carcinoma in Patients Undergoing Surveillance. Br. J. Cancer 2016, 114, 454-462. [CrossRef]

148. Chakraborty, C.; Wen, Z.-H.; Agoramoorthy, G.; Lin, C.-S. Therapeutic MicroRNA Delivery Strategies with Special Emphasis on Cancer Therapy and Tumorigenesis: Current Trends and Future Challenges. Curr. Drug Metab. 2016, 17, 469-477. [CrossRef]

149. Segal, M.; Slack, F.J. Challenges Identifying Efficacious MiRNA Therapeutics for Cancer. Expert Opin. Drug Discov. 2020, 15, 987-992. [CrossRef]

150. Van Rooij, E.; Marshall, W.S.; Olson, E.N. Toward MicroRNA-Based Therapeutics for Heart Disease-The Sense in Antisense. Circ. Res. 2008, 103, 919-928. [CrossRef]

151. Kauppinen, S.; Vester, B.; Wengel, J. Locked Nucleic Acid: High-Affinity Targeting of Complementary RNA for RNomics. Handb. Exp. Pharm. 2006, 173, 405-422. [CrossRef]

152. Gallo Cantafio, M.E.; Nielsen, B.S.; Mignogna, C.; Arbitrio, M.; Botta, C.; Frandsen, N.M.; Rolfo, C.; Tagliaferri, P.; Tassone, P.; Di Martino, M.T. Pharmacokinetics and Pharmacodynamics of a 13-Mer LNA-Inhibitor-MiR-221 in Mice and Non-Human Primates. Mol. Ther. Nucleic Acids 2016, 5, e326. [CrossRef] [PubMed]

153. Ebert, M.S.; Neilson, J.R.; Sharp, P.A. MicroRNA Sponges: Competitive Inhibitors of Small RNAs in Mammalian Cells. Nat. Methods 2007, 4, 721-726. [CrossRef]

154. Choi, W.Y.; Giraldez, A.J.; Schier, A.F. Target Protectors Reveal Dampening and Balancing of Nodal Agonist and Antagonist by MiR-430. Science 2007, 318, 271-274. [CrossRef] [PubMed]

155. Liu, Y.P.; Berkhout, B. MiRNA Cassettes in Viral Vectors: Problems and Solutions. Biochim. Biophys. Acta 2011, 1809, 732-745. [CrossRef]

156. Wang, H.; Jiang, Y.; Peng, H.; Chen, Y.; Zhu, P.; Huang, Y. Recent Progress in MicroRNA Delivery for Cancer Therapy by Non-Viral Synthetic Vectors. Adv. Drug Deliv. Rev. 2015, 81, 142-160. [CrossRef] [PubMed] 